\title{
Studies in the Phylogeny of the Filicales.
}

\section{On Metaxya and certain other relatively primitive Ferns.}

\author{
F. O. BOWER, Sc.D., F.R.S. \\ Regius Professor of Botany in the University of Glasgow.
}

\section{With Plates XXXII-XXXIV and two Figures in the Text.}

T $\mathrm{N}$ dealing phyletically with any large group of organisms, it is essential to strike a balance between relatively constant and relatively variable characters. The greater the constancy of a character the greater its value for the purpose of arrangement of the organisms in question, according to their natural relation by descent. The less constant features will take a subordinate place according to the degree of their fluctuation. This is the general principle which should underlie any natural system of classification.

In the case of the Filicales this simple and fundamental principle has often been neglected, and the remark applies not only to the characters used in the older systems, such as the sporangium and the sorus, but also to those newer characters in Ferns, which are beginning to derive an added clearness from the intensive study of their morphology and anatomy from a general and comparative point of view. In treating here of Metaxya, and certain other relatively primitive Ferns, the attempt will be made to assess at their proper value for phyletic purposes some of these characters ; and in particular to see whether the position which the sorus holds relative to the margin of the sporophyll is not a more reliable feature, in Ferns at large, than it has commonly been held to be. Certain facts which bear upon this question will be described first, and a discussion will follow on their use in the phyletic grouping of the Filicales.

\section{Metaxya, Presl, Tent. Pterid., I8 36.}

The genus Metaxya, the name of which was intended to imply an intermediate position, was constituted by Presl to receive one species. It was designated by him Metaxya rostrata, but it is now currently named Alsophila blechnoides, (Rich.) Hk. (see Christensen's 'Index Filicum', p. 40). This Fern has suffered vicissitudes of terminology, a fact which at once 
shows that cross relations exist, and suggests that it may be a synthetic type. It had been variously ascribed to Polypodium, Aspidium, Alsophila, and Amphidesmium before Presl placed it in a substantive genus by itself. Sir William Hooker introduced it as a substantive genus into his 'Genera Filicum', and figured it on his Plate XLII, B. It is noted as a very handsome genus of South American Ferns, allied in habit to Trichopteris. But in his 'Species Filicum' (vol. i, p. 3.5) he places Metaxya as a sub-genus of Alsophila; while later, in the 'Synopsis Filicum', it is no longer distinguished as a sub-genus, but is merged into Alsophila, appearing as its first species. Sir William Hooker thus took three successive steps in his treatment of the Fern. First, he accepted it as a valid genus (Gen. Fil.), then he reduced it to a sub-genus (Sp. Fil.), and finally he merged it in Alsophila (Syn. Fil.). Diels (Engler u. Prantl, i. 4, p. I32) adopts the middle position of Hooker. Christ ('Farnkräuter', p. 324) places it also as the first species of Alsophila, under the sub-genus Amphidesmium, Shott. A more divergent position is, however, taken by Grisebach ('Flora of the British W. Indian Islands,' p. 697), who places it in Polypodium $\$$ Phegopteris. It will be shown that a more exact examination of its details will tend to support the original position of Presl, and to uphold Metaxya as a genus distinct from Alsophila, and occupying an interesting position phyletically, which well justifies his old name for it.

The single species, Metaxya rostrata, is an inhabitant of Tropical America, and is well represented in herbaria. From inspection of dry specimens few would doubt that it is correctly given a place in relation to the Cyatheaceae, and especially with Alsophila. But to form an opinion on its true phyletic relation to these Ferns and others, it is desirable to make a revision of its details, anatomical and developmental, for which material properly preserved is necessary. This was kindly supplied by Mr. Stockdale, from British Guiana, and to him my best thanks are accordingly due.

It is a large handsome Fern, with creeping rhizome and leaves a metre long. These are borne in close succession, so that they may sometimes form a sort of terminal crown. The leaves are singly pinnate, with a hard smooth, dark-coloured rachis, while the numerous large pinnae are lanceolate, and slightly serrate at the tip; but lower down the margin is entire. The veins run parallel outwards from the thickened midrib, and are only occasionally forked. The internodes of the creeping axis vary in length. Branches are from time to time formed in relation to the leaf-bases. The bud appears on the abaxial side, and in the median plane of the leaf. In fact their position relative to the leaf is the same as in Lophosoria. Further, the pith of the bud (which as will be seen later is solenostelic) is continuous here also with that of the axis; that is, the solenostele inserts itself without closing upon the abaxial side of the undivided leaf-trace, as in Lophosoria.

At a short distance out from the midrib are the sori, and as one is 
frequently formed on each vein, they form an irregular line on each side of it. But, not uncommonly, two sori, or even more than two, may be borne on each vein, a feature which is specially noted by Presl as characteristic (1. c., p. 59). The sori project convexly from the lower surface of the leaf, and are slightly oval in outline, while numerous hairs project beyond the level of the densely grouped sporangia. A very good Habit-figure of the pinnae and sorus is given in Hooker's 'Genera Filicum', Tab. XLII, B.

The leaf is, apart from the sorus, destitute of hairs when mature. But the rhizome is permanently covered by a dense felt of brownish colour. The individual hairs are unbranched, and bear no terminal gland. They resemble, in fact, the unbranched hairs in Lophosoria. There is, however, no representative of the larger branched hairs, each borne upon an emergence, which are so marked a feature in that Fern, and are believed to prefigure the scales which are so prevalent in the Cyatheaceae. These, as well as scales, seem to be wanting in Metayxa.

It was chiefly the description of its anatomy, given by H. Karsten in his 'Vegetationsorgane der Palmen' (p. I25, and P1. IX, Figs. I-4), which led me to examine Lophosoria quadripinnata, (Gmel.). ${ }^{3}$ In referring to this work, and to Mettenius's memoir on Angiopteris, de Bary ('Comp. Anat.,' Engl. Edn., p. 286) persistently placed Alsophila blechnoides (= Metaxya rostrata, Presl) in juxtaposition with Lophosoria. Naturally curiosity was awakened to see what the structure of Metaxya really is, and this led to an inquiry for supplies from Mr. Stockdale.

Transverse sections of an internode of the rhizome show a complete solenostele, slightly oval in outline, as is the section itself. The structure is essentially the same as that of the horizontal runner of Lophosoria, except that the sclerenchymatous thickening of the walls of the ground tissue is in the old stock spread generally, instead of being restricted to definite bands, and that the solenostele, and especially the xylem of it, is rather thinner (Fig. I). A section, transversely through the petiole, discloses an uninterrupted leaf-trace, with the meristele crinkled, and the margins turned sharply inwards (Fig. 2). In the mature petiole the ground tissue becomes very hard and sclerotic. The vascular supply of the pinna comes off from the elbow of the petiolar strand, just as in Lophosoria (see Part II of these Studies ; 'Ann. of Bot.,' vol. xxvi, I9I 2, P1. XXXV, Fig. I4). But whereas in the large leaves of the latter Fern the petiolar meristele was apt to be divided into separate strands (1. c., Pl. XXXIV, Fig. 9), in Metaxya this has never been observed.

1 I wish here to acknowledge the friendly protest of Dr. Carl Christensen against my use of the specific name Lophosoria pruinata, Presl. He writes in a letter to me thus: "The species was described by Swartz as Polypodium glaucum. This name being invalidated by the earlier P. glaucum, Thbg., Gmelin renamed it $P$. quadripinnatum. Unaware of this new name Swartz himself renamed his species $P$. pruinatum. It seems to me that Gmelin's name must stand.' To this opinion I naturally assent.-F. O. 
The series of drawings, shown in Fig. 3, I-VI illustrate the general structure of the rhizome of Metaxya at the departure of a leaf-trace, and of its attendant abaxial bud. The series reads from the apex downwards, and the orientation is as in the creeping rhizome. Fig. 3, I, shows the leaf-trace in the petiolar base, approaching the foliar gap, while several roots are there seen traversing the cortex. In II a junction has been made near to, but not exactly at the lower margin of the leaf-gap, while it is seen that the incurved margin of the leaf-trace does not itself form the junction. In III, however, the flanges which projected inwards at the point of first junction have smoothed down, and slightly lower the opposite margin of the meristele joins the upper margin of the foliar gap. The section shown in IV traversed the bud which, as has been mentioned above, is frequently present on the abaxial side of the leaf-base. Its vascular supply, which is from the first solenostelic, arises, as in Lophosoria, as a diverticulum of the foliar trace, and the consequence is that the pith of the main axis is continuous with that of the runner. This is shown also in $\mathrm{v}$, which is added as supplying a fact which is unusual in the more primitive solenostelic Ferns, viz. the interruption of the solenostele by a perforation which is not a foliar gap. It is, in fact, similar in nature to those 'perforations' which are found in the more advanced types. This will be returned to later, as a fact of theoretical interest. Finally, as seen in VI, the irregularities caused by the insertion of the leaf and the runner being past, the regular solenostelic structure is resumed, and is interrupted only by the origin of the vascular supply to the roots. This comes off usually on the lower side of the creeping rhizome.

Passing to details, the meristele in the petiole is defined by a wellmarked endodermis, followed by a pericycle of one or two layers. The ' divergents' correspond to the convexities of the crinkled trace, and number from twenty to thirty in a full-sized trace. The protoxylem is not always clearly defined, while the tracheides often form only a single row. In the solenostele of the axis, which is delimited as before, the phloem is not profuse in quantity. The xylem-ring may consist of only three layers of tracheides, but in large rhizomes it usually comprises eight or more. There is no clearly defined protoxylem in the axis, and parenchyma cells are scattered through its xylem.

The sori of Metaxya have never been examined with the attention they deserve, considering how divergent are the vegetative characters of this Fern from those of the genus with which it has usually been placed. In point of fact the analysis of Sir William Hooker, published in $183^{8}$, still remains the best hitherto given. Examining the mature sorus from above, it will be found that the number of sporangia is far in excess of that in Lophosoria, or of any species of Gleichenia, while its form is that of a flattened oval mass, of rather large area (Fig. 4). Countings of the number of 
sporangia in a single sorus gave as results figures falling between fifty and hundred, while those of Lophosoria, or Gleichenia, vary from about sixteen downwards. Further, it will be seen that the orientation, as shown by the position of the annulus, is not uniform in the mature state, while the hairs which accompany the sporangia, being longer than they, are a prominent feature, as they are also in certain species of Alsophila, which were associated by Presl in his genus Trichopteris.

The sori originate as solid projections from the lower surface of the leaf, opposite a nascent vein (Fig. 5). The receptacle thus formed is massive, and, as seen in a section cut transversely to the vein, it is at first essentially like that of Lophosoria. It soon produces simple hairs and sporangia. The former are distributed generally over the surface of the receptacle, but are more numerous round the periphery; the sporangia are borne on the flattened apex, and as many as six or seven may be seen in a single transverse section, as against three in Lophosoria. The sporangia of a single sorus appear all of the same age; thus Metaxya is, like Lophosoria, technically a type of the Simplices, not of the Gradatae, like the other Cyatheoids with which it has habitually been ranked.

If vertical sections be cut so as to follow the course of the veins of the pinna, the sorus presents a very different appearance from anything seen in Lophosoria, or in any species of Gleichenia. The receptacle follows the course of the vein for some considerable distance. In the case shown in Fig. 6, its length is fully twice the width shown in Fig. 5. The sorus is in fact oval, while those of Lophosoria and of Gleichenia are circular. As before, hairs and sporangia, all of approximately the same age, are seen arising from the upper surface. Fig. 7 shows a more advanced sorus, cut transversely to the vein. The sporangia are further developed, but all still show approximately a like condition. Their segmentation is in all essentials the same as that in Lophosoria, though the type is less massive and the stalk thinner(cf. 'Ann. of Bot.,' I9I2, Pl. XXXV). It will be seen also that the vascular tissue extends into the receptacle, but here it is by arching outwards of the rows of tracheides from the vein, rather than by extension of a definite strand of tracheides into the receptacle. Lastly, if a tangential section be cut so as to traverse the stalks of the sporangia and the hairs, their distribution and structure are shown in Fig. 8. It is thus seen how the numerous hairs form an adequate protection to the young sporangia. The sporangial stalks show uniformity of structure and of orientation. The number of cells in the transverse section is usually four, corresponding to the four rows of cells of which the short stalk is composed.

In form the mature sporangia have a rather elongated form of the head, surrounded by an almost vertical annulus (Fig. 9, I-V). A feature of special importance is that the annulus is interrupted at the stalk, so that not only does the sporangium differ from those of the Cyatheaceae by the 
vertical position, but also by the interruption of the annulus. In form the sporangia are slightly flattened. In Fig. 9 I and III represent their flattened sides, with the cells of the annulus slightly collapsed on ripening; II and IV show them as seen on edge, and with the cells of the annulus fully convex. In Fig. 9, I, the face corresponding to the 'central' face of the Gleicheniaceous sporangium is shown. The annulus is definitely interrupted at the insertion of the stalk, and the cells on either side of the stalk are relatively thin-walled. On the side opposite the stomium the full induration begins at the third cell, and is continued for sixteen cells. Then follow two relatively thin-walled cells; next come the four cells of the stomium, encroaching in this view far over the face of the sporangium; and finally two thinner-walled cells follow, conneeting up with the stalk. The whole series numbers twenty-seven cells. The tabular cells are in this case only seventeen in number.

Fig. 9, II, represents a similar sporangium seen on edge with the base of one of the hairs $(h)$ attached to its stalk. The convexity of its sides is seen, while twelve cells of the annulus are visible. Of these the two lowest correspond to the two thinner-walled cells in Fig. 9, I. The third drawing (Fig. 9, III), which was made from a rather peculiar sporangium, represents the opposite face to that shown in Fig. 9, I, viz. that which corresponds to the 'peripheral ' face in Gleichenia. It is, moreover, to be noted that the sporangium here represented was the 'looking-glass' image of that in Fig. 9, I, as regards the side on which the stomium occurs. The fact may be stated thus: that in these sporangia as viewed from the peripheral side the stomium may be either right or left; in Fig. 9, I, which is seen from the 'central' side, it is right; in Fig. 9, III, which is here seen from the 'peripheral' face, it is also to the right, which could only happen if they were 'lookingglass' images of one another. The peculiarity of the sporangium seen in Fig. 9, III, consists in the annulus being continuous across the insertion of the stalk, a condition not unique, but less common than the interrupted state; and the number of the cells of the annulus is here rather larger than in the previous case, viz. thirty. The stomium is as before, but it is seen that its four cells do not encroach upon the 'peripheral' face as they did upon the 'central' face of the sporangium in Fig. 9, I. It thus appears that the stomium is not laterally symmetrical. The number of tabular cells of the 'peripheral' face is here larger, viz. twenty-five.

The next drawing, Fig. 9, IV, shows an average sporangium on edge, presenting its stomium in surface view. The relation which this bears to the annulus and to the 'peripheral' face of the sporangium is the same as before seen in Fig. 9, I. The 'central' face, upon which the cells of the stomium encroach, is to the left, while the 'peripheral ' is behind and to the right, owing to slight obliquity in position of the sporangium. Lastly, the stalk shows in Fig. 9, II, four cell-rows, and in Fig. 9, I and IV, 
each three, but in Fig. 9, III, only two. These facts are consistent with the stalk being composed of four rows of cells, as will be seen to be the case from transverse sections.

These drawings give a comprehensive idea of the external characters of the sporangium of Metaxya. It should be compared with that of Lophosoria, since there is so obvious a similarity between these types of Ferns. By comparison with $\mathrm{Pl}$. $\mathrm{XXXV}$, 'Annals of Botany,' 19I2, which illustrates Losophoria, it will be seen that not only are the sporangia of Metaxya much smaller, but also more elongated, and composed of fewer cells. For instance, the cells of the complete annulus in Fig. I 8 of Lophosoria total 39, those in Fig. 9, I, of Metaxya are only 27, and in Fig. 9, III, 25. Or again, the cells on the peripheral face of the sporangium of Lophosoria shown in Fig. I 8 of Pl. XXXV (1912) number 60, but those in Fig. 9, I, of Metaxya are 17, or in Fig. 9, III, they are 25. The number of cell-rows composing the stalk is also smaller. Lastly, there is the very essential difference in the position and interruption of the annulus. This is in Lophosoria markedly oblique, and continuous; in Metaxya it is as a rule interrupted at the stalk, and shows only traces of the oblique position, being almost vertical. Moreover, the stomium is ill-defined in Lophosoria, but in Metaxya it appears of the well-defined type characteristic of so many of the advanced Leptosporangiate Ferns. The spore-output per sporangium appears to be the usual number of 64 .

In writing some time ago on the sorus of Gleichenia, it was pointed out ('Ann. of Bot.,' xxvi, p. 275) that in G.pectinata the Gleicheniaceous type of sorus has reached the point of ineffectiveness in its increase in number of sporangia, since they are so closely packed that, being all of like age and dehiscing by a median slit, they cannot shed their spores when ripe. It was shown that there are four possible ways out of the difficulty, which may be adopted singly or in combination: (I) by increasing the length of the sporangial stalk, (2) by adopting a lateral dehiscence, (3) by extending the area of the sorus, or (4) by elongating the receptacle. Gleichenia adopted none of these, but other Ferns did, and have progressed as a consequence. Metaxya is one of them. Its receptacle has remained of about the same height as in Gleichenia, but its area is greatly enlarged, while the sporangia have lateral dehiscence, and are rather longer stalked. Thus a combination of three of the modifications above noted is to be found in the sori of Metaxya. The transverse dehiscence is shared by all the more advanced Leptosporangiate Ferns. The elongation of the stalk is here only relatively slight. It is the increase of the area of the receptacle which is the most marked feature, which in the absence of any elongation of the receptacle makes the large number of sporangia in the simple sorus of Metaxya a practical possibility. It is naturally to certain sections of the comprehensive genus Polypodium that we shall look for conditions which 
parallel these : and in point of fact Metaxya was included in Polypodium by several of the early authors. But it is to be remembered that there the sorus is a mixed one, while here all the sporangia arise simultaneously. The further discussion of this point will be reserved for the concluding part of the memoir.

From the characters detailed above there is sufficient ground for upholding Presl's view that Metaxya should be regarded as a substantive genus. The characters which mark it off from Alsophila, the genus to which it had been attached by Sir William Hooker and others, are the creeping habit, the unbranched hairs and the absence of scales, the solenostelic structure of the axis without medullary strands, the undivided leaf-trace, and, most important of all, the characters of the sorus and sporangium; these are the flattened and enlarged receptacle, the simultaneous origin of the sporangia, the almost vertical annulus, and its interruption at the insertion of the stalk. The Fern is technically one of the Simplices, for all its sporangia arise simultaneously, a character which it shares with Lophosoria. In fact, these two monotypic genera lie aloof from the Cyatheaceae, and show characters both anatomical and soral which are more primitive than theirs, while the fact that the dermal appendages in both are hairs, not scales, points to the same conclusion. On the other hand, the two genera are clearly allied to one another. This comes out not only in the characters named, but also in the peculiar relation of their runners to the leaves, and in the attachment of their vascular supply to that of the leaf. They differ, however, in their sori and sporangia; for while Lophosoria has few large and stout sporangia with a complete oblique annulus, Metaxya has a very large number of smaller sporangia in each sorus, but the annulus is almost perfectly vertical, and is interrupted at the stalk. It has been shown in a previous memoir that Lophosoria possesses characters reminiscent of the Mertensia section of Gleichenia. Metaxya shares with both the creeping habit, solenostelic structure, and undivided leaf-trace, dermal hairs, and simple simultaneous sorus. But the divergence from that type is seen in Lophosoria in the upright habit and sometimes divided leaf-trace; in Metaxya it appears in the soral characters rather than in habit or anatomy.

\section{Hemitelia setosa, (Klf.) MetT.}

Having thus seen two Ferns with undoubted Cyatheaceous affinity, both showing a solenostelic structure, and most markedly in axes with a prone habit, it became a question of interest whether any of the true Cyatheaceae show similar characters. Gwynne-Vaughan, in his second memoir on Solenostelic Ferns ('Ann. of Bot.,' xvii, p. 7 Io), has pointed out how Alsophila excelsa in its sporeling stage actually passes through such a condition of solenostely in its upright axis, but rapidly becomes dictyostelic by overlapping of the leaf-gaps. It would seem probable that if any 
true Cyatheoid Fern bore runners like those of Lophosoria or Metaxya, these would probably be solenostelic. The fact that they may be is illustrated in the case of Hemitelia setosa. On a large plant of that species, in the Edinburgh Botanic Garden, there was borne an underground runner, which after a horizontal course turned above ground as an upright leafy shoot. I here acknowledge the kindness of the Director in having it cut off close to the main stock and sent to me. It was over $I \frac{1}{2}$ inches in diameter, and very fleshy, though covered by an external band of brown sclerenchyma. But when cut in transverse section it showed an advanced type of Cyatheoid structure, with dictyostele showing commonly three leaf-gaps in one transverse section; there were also numerous strands forming a medullary system. Thus the thick runner carried no special interest, as bearing on the present question.

A second runner of smaller size was, however, found arising laterally from the larger runner, and presenting externally an appearance not unlike those of Lophosoria. This was cut into sections, and was found to be solenostelic (Fig. IO). It will be noted that in the central medulla two small strands are present, showing that even at an early stage in a small runner the medullary system may be constituted (m.s.). A special interest attaches to the vascular supply at the base of the small runner for comparison with that in Lophosoria. So transverse sections were cut to its extreme base, and it was found that the solenostele did not close at insertion on that of the main shoot, but remained an open ring with a massive cylinder of pith. This, in the case in point, was still traversed by the two small strands, which passed down through the open tube to connect with the medullary system of the main axis. Except for the existence of these medullary strands, the arrangement is essentially as in Lophosoria. But the presence of a medullary system may be held as a feature of advance, which has a parallel in other characters of Hemitelia, such as the greater disintegration of the leaf-trace, the presence of dermal scales, of a partial indusium, and a basipetal succession of the sporangia in the sorus, as against the more concrete leaf-trace, the absence of scales and of any indusium, and the simultaneous origin of the sporangia in Lophosoria. Thus, though Hemitelia setosa shows these characters of advance, it also shows the interesting primitive feature of solenostely in its small runner.

But this is not the first example of pronounced solenostely which has been described among Cyatheoid Ferns with a basipetal sorus. The old observations of Stenzel on Alsophila aculeata ${ }^{1}$ show an example which corresponds very closely with those above described. From an old stock numerous runners arise, each related to a leaf-base as in Lophosoria; while their anatomy showed at least in their lower region an uninterrupted tube. These runners, as in Lophosoria, usually turned downwards at first, and

1 Verhandl. d. K. Leop. Carol. Akad. d. Naturforscher, I86I, p. I6, Tab. I, II. 
bore on their surface the bases of arrested leaves; but some grew upwards at once. Anatomically they ultimately repeated the structure of the main axis. But at the extreme base Stenzel describes the stele as a simple strand ('einfacher Faden'), and he explains that only where the branch emerges from the cortex of the parent plant does the stele widen out, 'like a filter,' and then, growing on as a cylinder, forms the vascular tube of the branch. In this case the structure of the young runner appears to have been more rudimentary at first than that in Lophosoria or Metaxya; it corresponds more nearly with that in Cibotium Barometz, to be described below ; but the contracted region of the stele is longer continued in the Alsophila than in that Fern. Doubtless there is considerable variation between species in this, which is a feature probably dependent in some degree upon the strength of development of the individual runner.

These facts from Alsophila and Hemitelia suggested a like inquiry for Cyathea, and naturally the soboliferous species Cyathea mexicana, Schlecht and Cham, was used, material being available from the Glasgow Garden. The buds are very numerous ; their position is sometimes below the leafbase, as in Lophosoria; sometimes more than one may be found there. Transverse sections of the upper part of one of these shoots show the ordinary Cyatheaceous structure. Towards the base it closes into a solenostele which narrows basally, but in the material examined it was not found to contract to the Lindsaya condition. It is thus seen that all the genera of Cyatheae may form runners, as a rule on the abaxial side of the leaf-base ; and in all of them the basal region shows a simpler vascular arrangement than the mature Cyatheaceous structure. In all of them the solenostelic type is present at least for a greater or less distance from the extreme base.

In Lophosoria and Metaxya we see two genera naturally related to the Cyatheae, with which they have always been classified. But they differ from them (i) in their habit, which in Metaxya is permanently trailing, in Lophosoria it is temporarily so in the runners; (ii) in their pronounced solenostely; (iii) in their undivided, or in Lophosoria only slightly divided, leaf-trace; (iv) in their dermal appendages being hairs, not scales ; (v) in the simple character of the sorus; (vi) in the details of their sporangia. All these characters indicate for them a relatively primitive position at the base of the Cyatheoid series, while they link it to the Gleicheniaceae. It was concluded in a previous memoir ('Ann. of Bot.', xxvi, p. 269) from comparisons of Lophosoria on the one hand with the Gleicheniaceae, and on the other with the Cyatheae, that the creeping habit was relatively primitive, and that the upright axis of the Cyatheaceous Tree-ferns was a secondary derivative from it. This conclusion is very greatly strengthened by the additional facts from Metaxya. For this Fern shows dorsiventrality more fully and permanently than Lophosoria, and with it the solenostelic struc- 
ture ; and this goes along with other primitive characters named. We may now therefore conclude more confidently than before that in the Cyatheae the dendroid type is secondary and derivative.

\section{DICKSONIEAE.}

But there is the other family of dendroid Ferns to be considered, viz. the Dicksonieae. They are clearly marked off from the Cyatheae by the position of their sori. While these in the Cyatheae are constantly superficial in origin, as in the Gleicheniaceae, the Dicksonieae have their sori as constantly marginal in origin, corresponding in this feature to the Schizaeaceae. Prantl has demonstrated the marginal origin of the sporangia in the various genera of the Schizaeaceae in his great monograph on the family ('Schizaeaceen,' pp. 39-45). But the detailed evidence has never been fully given for the Dicksonieae, so as to relate the origin of the receptacle of the sorus, or the sporangia themselves, distinctly to the marginal series of cells of the developing leaf. It has been stated by Burck ('Indusium der Varens,' p. 43) and by Gluick ('Die Sporophyll-Metamorphose', Flora, I895, p. I9) that it is so; but the mere statement that it is so, without the recognition of the segmentation which leads to it, amounts to nothing more than a bare assertion. On the other hand, the present Fig. I I of Dicksonia Scheidei demonstrates the segmentation of the leaf-margin, and how while the lower and upper indusium flaps arise as upgrowths from the surfaces of the leaf, the receptacle originates from the marginal cell itself of the section. It will be shown below that the same holds also for various members of the Dicksonieae and other related Ferns. We may provisionally accept the essential distinctness of the Cyatheae from the Dicksonieae, as based upon this constant difference of origin of their sori. The question will now be taken up of the habit and structure of the Dicksonieae for comparison with what has been seen in the Cyatheae.

Gwynne-Vaughan, in his papers on Solenostelic Ferns ('Ann. of Bot.,' vol. xvii, p. 689 , \&c.), has dealt with various types which belong to the Dicksonieae, and in fact his best examples have come from that family, or its immediate derivatives. He has described for Cibotium (Dicksonia) Barometz how the stelar condition 'must be regarded as dictyostelic, although it is very near solenostely'. The overlapping of the leaf-gaps, which he noted, depends on the degree of elongation of the creeping axis; where the internodes are relatively long the solenostelic state, without any medullary strands, is typically seen in the bulky axis. As he points out (1. c. p. 709), lateral shoots are formed 'at the back of the leaf-trace'; in fact, they correspond in position to those of Lophosoria, or Metaxya. Thus C. Barometz may be held to have, as regards habit and vascular structure, a similar relation to the dendroid Dicksonieae to that which Metaxya bears to the dendroid Cyatheae. The examination of its runner, or lateral 
shoot, shows very similar results. Sections at various levels from its apex downwards are seen in Fig. I2, I-VI. The first (I) shows the young axis with a complete solenostele, and laterally the lowest leaf of the shoot is attached, with its leaf-trace divided into five strands. In II the solenostele has opened, and the leaf-trace, now reduced to four strands, is moving towards the leaf-gap, which it joins first by one margin (III), finally by both; but even after this is accomplished the divisions of the leaf-trace into separate strands may remain (IV). Later the ring is completed (V). Passing downwards the solenostele contracts, and the central pith is reduced until it finally disappears, together with the internal endodermis (VI). The central mass of soft tissue has the appearance of phloem, but isolated tracheides are not uncommon near its margin (Fig. I3). Towards the base of the shoot the soft tissue becomes still more reduced. In essentials this behaviour is as in Metaxya and Lophosoria, but at the base of the bud the stelar structure is of a more primitive type than in those Ferns.

A still more interesting type is seen in Thyrsopteris elegans, which has already been shown to have a truly marginal sorus, with the first sporangia springing from the very apex of it ('Land Flora,' p. 588, Fig. 329). As the vascular structure of Cibotium and Dicksonia is now fairly well known, it seemed desirable to obtain like facts for Thyrsopteris also, since that Fern has sori so like those of the Dicksonieae, though in some ways more primitive than they. The plant shows in less degree than Dicksonia the dendroid habit: it is in fact a stunted type of Tree-fern. The published descriptions of its habit are not very explicit. Kunze ('Die Farrenkräuter,' p. 3) says that 'the stem or root-stock is hitherto unknown'. Hooker ('Species Filicum,' i, p. 64) describes it as 'arborescent?', and quotes Kunze's remark that 'this Fern is said to have a caudex as thick as a walking-stick, whence it is supposed to be arborescent'. Diels, however ('Nat. Pflanzenfam.,' i. 4, pp. I22-3), describes the stem as attaining $I \frac{1}{2}$ metres in height, but as thick as the thigh, and closely covered by the scars of old leaves. Christ ('Farnkräuter,' p. 33I) quotes the same words, but adds that no trace of a creeping rhizome is present. There are now well-developed plants growing in Kew and in Edinburgh, and smaller specimens in other collections. In Glasgow we have some received by gift from the Edinburgh Botanic Garden, for which I record my thanks to the Director, others obtained by purchase.

The fact that a strong bud may come above ground at some distance from the parent plant, as seen at Kew and in Edinburgh, indicates the presence of a 'runner' like those of the Cyatheoids. One of the young plants given from the Edinburgh garden was shaken out from the soil, and showed a massive piece of axis, about 2 inches long, from which arose two long thin runners, with stunted leaves and long internodes. One of these had come above ground, and bore foliage leaves. The insertion of the runners 
was essentially the same as in other cases, viz. on the back of the leaf-base. The material was thus at hand for anatomical observation. Externally, the surface was covered by dermal appendages. These were of two sorts : soft woolly, but unbranched hairs, and in less numbers long stiff dark-coloured bristles ('Borsten').

If a section be cut of the petiole of a small leaf, an undivided horseshoe-shaped trace is seen, with incurved margins, and not very markedly crinkled. The xylem is more massive in the neighbourhood of the marginal crooks, but towards the median plane it thins out to a single layer of tracheides (Fig. I5, c). In a large leaf the trace may be separated into three portions (Fig. 14), having the same relative positions as those in Lophosoria (see 'Ann. of Bot.,' xxvi, p. 284). The trace is very much convoluted and crinkled and the number of the 'divergents' is very large, as many as eighty having been counted.

Where the axis is small, for instance about the base of a small runner, its vascular system may be a simple solenostele (Fig. 15, a). But where larger, a single strand, or sometimes more than one, may be found in the pith (Fig. I5, b). Tracing the origin of the medullary strand it is found that it separates at the opening of the leaf-gap preparatory to receiving the leaf-trace, as described by Gwynne-Vaughan for Pteris elata, or Dennstaedtia rubiginosa ('Ann. of Bot.,' xvii, Pl. XXXIII, Figs. I3, I4). It runs down the centre of the pith, and frequently ends blind where the runner is small; but in stronger axes it may connect up with that from the next lower leafgap, and constitute a continuous rod. In larger shoots the same method is found, but the medullary strands connect so as to form a considerable medullary system. This is illustrated by the series of sections shown in Text-fig. A, I-8, which show transverse sections taken at short intervals from a thick stock, and arranged in succession from below upwards. In all of the sections it will be seen that the continuity of the solenostele as a ring is unbroken, even where a leaf-trace is being given off. This is a point of difference from what is seen in the young runner, where the ring opens on the giving off of a leaf-trace. This continuity is maintained in the old stem by a broad strap of vascular tissue - the compensation strand, or tongue of Tansley ('Ann. of Bot.,' xix, p. 507, \&c.), which connects with the medullary system. It is in fact the correlative of the small strand already noticed in young runners (Fig. I5), and it arises like it from the anterior margin of the foliar gap. But notwithstanding the fact that the ring as seen in transverse section appears always as a complete one, there is still indirect communication between the outer parenchymatous system and the inner by a passage down the hollow of the gutter-shaped trace.

The sections may now be described in detail. In Text-fig. A I, 2, 3 show the steps of separation of the leaf-trace $(a)$, and in 4 the petiole itself has separated from the axis, leaving only a flattened side to the section. 
In I the leaf-trace appears as a projecting thinner part of the solenostele showing already the crinkled outline characteristic of the leaf-trace. Opposite it is a broad vascular strap-the compensation tongue. Two other leaf-traces $(b, c)$ are already indicated by thinner regions of the ring. The medullary system consists of several strands of various size, disposed roughly in a ring, two lying irregularly near to the centre. In Text-fig. A, 2, the compensation tongue has fused at its margins with the incurved sides of the foliar gap, while processes which will form the hooks of the leaf-trace point inwards into the space thus enclosed. The medullary strands are disposing themselves in a circle with a central strand. This arrangement becomes clearer in 3 and 4 , which also show the final separation of

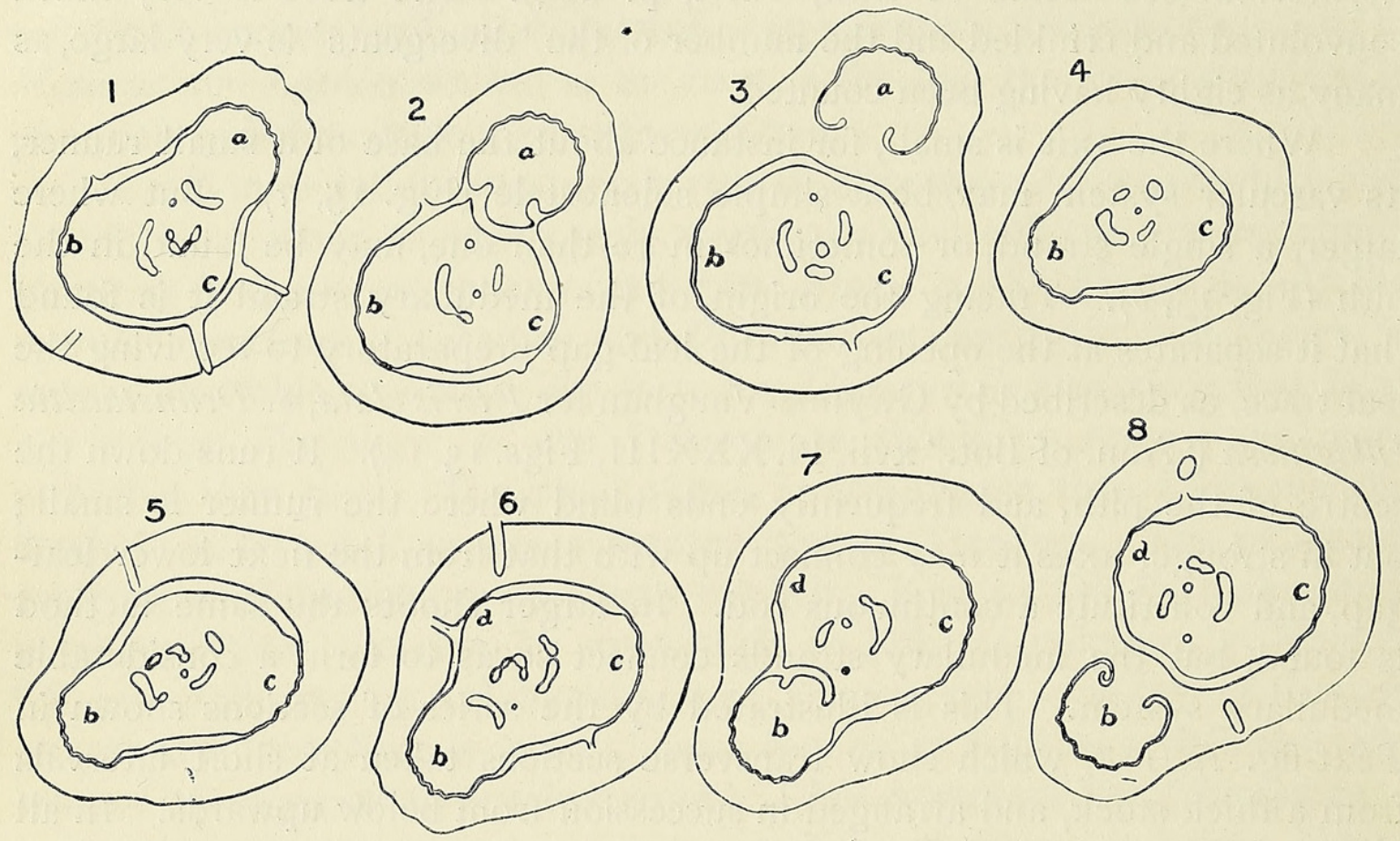

Text-Fig. A.

the leaf-trace (3), and of the petiole itself (4). Meanwhile, the traces $b$ and $c$ have become more definite, and in 5 the trace $b$ appears as a thinner region strongly arching outwards. Opposite the gap thus forming, the broad compensation tongue already recognizable in 3 and 4 is moving outwards to the gap. In 6,7 , and 8 the stages already followed above for the trace $a$ are repeated, with the same result. It is to be noted that already in 8 the compensation tongue for the leaf-gap $c$ has been formed from the medullary system. From these drawings the plan of the vascular system of the shoot is sufficiently indicated. It is polycyclic, the outermost cycle being a closed solenostele: the middle cycle is somewhat irregular, but is fairly constant, with its connexion outwards at each leaf-gap with the solenostele. Centrally is a simple strand of rather irregular position, which appears to connect with the middle cycle 
at or near to the exit of each leaf-trace. The stem of Thyrsopteris is said by Diels to attain the thickness of a man's thigh. In such stems it is probable that the vascular system may show greater complexity of polycycly than is here described. But this has not yet been seen.

\section{SACCOLOMA.}

Of Ferns whose structure has hitherto been figured and described, the nearest correspondence to these details of Thyrsopteris is found in a stock examined by H. Karsten ('Vegetationsorgane der Palmen,' I847, Pl. IX, Figs. 5 and 6), and described under the name of Dicksonia Lindeni. $\mathrm{He}$ speaks of the Fern as having an upright axis, while it had runners springing from the leaf-bases, and their vascular supply came off as a conical or cylindrical bulging of the vascular cylinder of the main shoot. This is as in Lophosoria and Metaxya, or in Thyrsopteris itself, while the habit appears to have been like that of Thyrsopteris, having like it runners which may rise upright when strong enough. He found the full-grown stem to be polycyclic. The outermost ring was a complete solenostele, as in Thyrsopteris, but in his Fig. 6 it is interrupted at one point close to the outgoing leaf-trace. A second ring lay within, more regular and connected than that seen in Thyrsopteris, and opposite an outgoing leaf-trace in Fig. 6 a compensation tongue is clearly shown.

The Fern named Dicksonia Lindeni by Karsten is now recognized as a variety of Saccoloma domingense, (Spr.) Prantl (see Prantl, 'Arb. K. Bot. Gart. zu Breslau,' I893, p. I9; also Christensen, 'Index Filicum'). This suggests further comparison with the well-known drawings of Mettenius of Saccoloma elegans. ${ }^{1}$ The details are slightly different, and the stock requires a full elucidation; but the main features appear to be the same. The further question, however, arises as to the sorus of Saccoloma. Is its receptacle, like those of Dicksonia and Thyrsopteris, of truly marginal origin? This point has been examined on material of Saccoloma elegans collected in Jamaica. Unfortunately, owing to the seasonal condition of the plant, it was not possible in August, 1909, to obtain all stages of the development, but enough was secured to show that the receptacle is of exact marginal origin.

This is shown by the Figs. I6, $a, b$. In the first of these $(a)$ a leafmargin is shown with regular segmentation and a marginal cell ; it is, however, becoming rounded off prior to the formation of the sorus. Fig. I6, $b$, shows a more advanced state, in which the alternate segmentation is still readily recognized, and the marginal cell occupies a median position. But the development of the two sides has become unequal, and already the two lips of the indusium appear as swellings on either side of the slightly conical receptacle, the centre of which is occupied by the marginal cell itself. It

${ }^{1}$ Abhandl. a. d. K. Sächs. Ges. d. Wiss., vi (1863), p. 53I, P1. VI, Figs. I-4. S. elegans is a synonym for $S$, domingense, Prantl, 
will be noticed that of the two indusial lips that on the abaxial (lower) side at first develops the stronger, and the whole sorus comes to be tilted over to the adaxial side. The same is also the case, though in less degree, in Dicksonia (Fig. II) and in Odontosoria (see below, Fig. I7). In later stages this inequality is made up, and even reversed, so that in the final state the sorus in all of these Ferns appears to be shifted distinctly to the lower side, while the upper flaps of the successive sori fuse laterally to form a continuous flange (compare Kunze, 'Farrenkräuter,' Taf. XLI, c). This is particularly well shown in Goebel's Fig. IO, 'Flora,' I9I2, p. 47, and he describes the nature of the sorus of Saccoloma thus: 'That which has been described as the "scarcely modified leaf-margin" is composed of the contiguous outer flaps of a two-flapped indusium. These outer flaps are larger than the inner. Still one sees the several sori clearly limited by a seam-like swelling, so that there can be no doubt of the interpretation thus given,' \&c. The facts of development above given fully demonstrate the correctness of this conclusion, while comparison of other species, as well as with species of Davallia, further strengthen the position. Still the sori themselves remain distinct, each with its own separate receptacle, and with the 'inner' or lower flap of the indusium separate also for each individual sorus.

Owing to the fact that my Jamaican material presented an incomplete series of stages for developmental study, a full account cannot be given at present for Saccoloma. But enough has been seen from rather advanced conditions of the sori to make it certain that a one-sided gradation of origin of the sporangia is present. The most advanced sporangia are those nearest to the lower or 'inner' flap of the indusium, while passing from these towards the upper or 'outer' flaps, which are fused as a false 'leaf-margin', a succession of younger sporangia is seen. The sorus has, in fact, undergone just such a modification as might have been anticipated in a type of marginal origin, with equal development on both sides, which had become phyletically shifted to the lower surface of the leaf, with consequent unequal development of its sides. Moreover the biological advantage of such protection is too obvious to need detailed explanation.

As regards the dermal appendages, broad brown scales are found in Saccoloma elegans, together with simple hairs. They all fall away, however, from the leaves at an early stage, and in the mature state the surfaces of the lamina and the petiole are quite bare. Thus as regards the anatomy Saccoloma appears to be closely linked with the relatively primitive Thyrsopteris, which had itself arrived at a condition advanced in anatomical complexity when compared with Cibotium Barometz. In point of dermal appendages it is advanced relatively to both of them ; also in its partial merging of the sori, and in their one-sided, gradate sequence of sporangia. The sum of these characters will give it a higher phyletic position than the Dicksonieae, though the anatomy will leave little doubt of its natural affinity with this family. 


\section{LINDSAYA. ODONTOSORIA.}

The close relation of the individual sori of the marginal series in Saccoloma only involves their indusium, of which the 'upper' flap is merged into an apparent leaf-margin, though the 'lower' flaps of the individual sori remain separate. But in Lindsaya and some other Davallieae both flaps merge, while the receptacles also become continuous as a marginal, or apparently intramarginal, flange. The clear indication of what has occurred is found by comparison of individual cases where the fusion is incomplete. Some of these will be described below.

On the other hand, the vascular construction of the stem of Lindsaya, as described by Tansley ('Ann. of Bot.,' xvi, March, I902), is of a type which may be held as more primitive than that of any solenostelic Fern. We see the stage of structure, which in Lindsaya is permanent, rapidly passed through in the runner of Cibotium Barometz, and it probably figures in the early development of many Ferns. In fact, the axis of Lindsaya appears to have retained permanently a condition which is only rudimentary and transitional elsewhere. Thus, anatomically, Lindsaya stands on a relatively low plane, though its soral condition is relatively advanced.

The developmental tendencies of the Davallieae, as they affect the sori, are towards their passage from the margin to the lower surface, and towards their fusion. These modifications, combined with some others, do not necessarily progress on parallel lines, with the result that there is some difficulty in the grouping of the different forms, and synonymy is profuse and confusing. The two plants on which observations have been made are Odontosoria retusa, (Cav.) J. Sm., and Lindsaya lancea, (L.) Bedd. The former was supplied from the Edinburgh Botanic Garden, the latter collected in Jamaica. The material of the latter was insufficient for a complete study of the development, but it sufficed to show that the condition is essentially similar to that seen in Odontosoria, which was more fully examined. As in Saccoloma, the first indication of the future sorus is a flattening of the margin on the young pinnule (Fig. I7, a). The construction of it has been by successive segments cut off from a marginal cell, which still retains its identity, but it lags behind the last segments in its activity of growth, so that these overtop it right and left (Fig. I $7, b)$. That on the abaxial side takes the lead slightly over the other, so that the receptacle, in which the marginal cell is still visible, takes an oblique slope. This is maintained even in later stages, though, owing to stronger growth, the adaxial or ' upper' lip of the indusium soon overtops the abaxial or 'lower' (Fig. I8). The vascular tissues develop in the region below the receptacle, and as a vascular commissure there links the several veins together laterally, each vertical section shows a more or less prominent mass of tracheides spreading below the receptacular surface. On the latter the sporangia begin to 
appear, and the largest constantly occupies a position which is at least near to, if not actually coincident with, the margin of the pinna. Other sporangia appear later in lateral positions, mostly on the adaxial side. Hairs are also formed in considerable numbers. A transverse section of a sorus at this stage is shown in Fig. 19, and from such a section it is clearly proved that the sorus, though continuous and marginal, is essentially a gradate one in its early stages. The oldest sporangia form a fairly regular series in a central position between the indusial lips, while those which follow are laterally placed. It will be noted that the early segmentation of the sporangia is such as to produce a fairly massive stalk, and resembles that of the Gradatae generally. A further point for note is the irregular lobing of the indusial lips (Fig. I8). The laciniae thus produced are chiefly upon the lower lip, and they are a more marked feature in O. retusa than in $L$. lancea. It is also seen that while the lips are only slightly unequal in $O$. retusa, and the sorus consequently appears terminal, they are much more unequal in L. lancea (Fig. 20); and the sorus is distinctly intramarginal (Fig. 2I). The sporangia are closely packed between the lips in the latter Fern, and arise in the later stages of the sorus after the manner of the Mixtae. But the sequence is not long continued; in fact, neither Odontosoria nor Lindsaya appear to be at all pronounced cases of the mixed condition of the sorus.

It is thus seen that the sori of the Ferns above described are in an intermediate condition between the Gradate and the Mixed types. The receptacle, usually a projecting body in the Gradatae, has become flattened (Fig. I 8), and the basipetal sequence, though it can be traced in the younger stages, is not strictly adhered to. This at once suggests the question whether the position of the annulus is oblique, as in the Gradatae, or vertical, as in the Mixtae. A similar question would apply to Saccoloma. Unfortunately, the Jamaican material did not suffice to decide the question for that Fern or for Lindsaya lancea, though in both cases evidence of an oblique position of the annulus was seen. But examination of the sporangia, both in Odontosoria retusa, (Cav.) J. Sm., and in Lindsaya repens, (Bory) Bedd., ${ }^{1}$ showed that in certain sporangia the annulus was clearly oblique, and the sequence of its cells was not interrupted at the insertion of the stalk. There is, however, some variety of detail in different sporangia. In Fig. 22 an example is shown of the sporangium of Lindsaya repens, in which, though the induration of the ring stops opposite the insertion of the stalk, still the sequence of cells is continued past it, so that a complete oblique ring is present, as in the Dicksonieae. A similar condition has been observed in Odontosoria retusa. Here again, though the induration ceases opposite to the stalk, the series of cells of the annulus is continued past it. This con-

1 This plant is named in the Synopsis Filicum Davallia (Odont.) repens, Desv., and Hooker there notes that its place is 'quite doubtful between Odontosoria and Lindsaya'. 
dition, which thus is seen in both species, is not uniform for either. Both are variable. It is, however, a condition which would naturally be anticipated in Ferns of Gradate origin, in which the receptacle was flattened and the sorus (with a tendency to becoming a mixed one) compressed laterally between the indusial lips. The sporangia, in such a case, would be forced to open upwards, and for this a vertical annulus would be the proper mechanism, while the induration of its basal region would be mechanically ineffective. Such conditions as those seen in the Ferns named give a strong support to the view that the Lindsaya-Davallia type has been derived from some Gradate, and probably from a Dicksonioid source.

\section{Davallia.}

Having touched upon Ferns so nearly related to Davallia as those last mentioned, it is necessary briefly to allude to this genus. But it would be impossible in this memoir to do more than take a single sample of the species, and examine its sorus developmentally. A thorough comparative study of the sori of the genus is urgently wanted, which would probably lead to the recognition of many details conducive to a phyletic grouping of the Ferns of this affinity. This can only be suggested at present in the roughest outline. It is already known that the sori of certain Davallias show a mixed condition, but that in their earliest stages the first sporangia arise in a median position, which may be taken as a reminiscence of a basipetal sequence in their ancestry ('Phil. Trans.,' vol. cxcii, p. 76). This fact was seen in $D$. Griffithiana, which later shows very clearly a mixed condition (1. c., Figs. 134, I35). It must remain for further inquiry to show, for the various species, what balance there may be between the originally basipetal and the derivative mixed condition of the sorus in the genus at large.

But the question of present interest for us is the position of the sorus at its initiation : is it in the first instance marginal ? This point has been examined in $D$. pentaphylla, Bl., a species in which, when mature, the sori are distinctly intramarginal, though not in so high a degree as in some species. Sections through very young sori prove that the origin of the sorus is nevertheless truly marginal, as in the related genera above described. Fig. 23 shows a very young state in $D$. pentaphylla, in which the receptacle lies between the two marginal flaps, and itself holds a marginal position. The two indusia differ, however, slightly from the first in bulk and in structure. That which is to be the lower $(l)$ takes the precedence while young, but it is the less bulky, running out later into a single layer of cells (Fig. 24, l). The upper lip, which extends, as in Lindsaya and Saccoloma, as an apparent extension of the leaf-surface when mature, hangs back slightly at first (Fig. 24, $u$ ), but is more bulky, consisting throughout of several layers of cells. It shows at first a marginal segmentation, but this soon ceases, and the greater part of the mature flap, which then appears like 
a continuation of the flattened pinna, consists of tissue produced by intercalary growth, signs of which are already seen in Fig. 24.

It may be a question what exact relation the two indusial flaps bear to the marginal segmentation of the pinna. Some sections give the appearance as though the succession of segmentation was continued directly into the marginal segmentation of the upper flap, a condition not improbable, seeing that it becomes ultimately so much the larger. The exact genetic relations in Fig. 23 seem uncertain on this point. But whatever these relations may actually be, there can be no reason to doubt the substantial correspondence of the receptacle and the two flaps with the correlative parts seen in Lindsaya and Saccoloma, and ultimately in Dicksonia and Thyrsopteris. It may, in fact, be considered as conclusive that the sorus in Davallia is of the marginal type.

Such questions in Davallia become more insistent in Nephrolepis and Oleandra, genera which have usually been classified with the Davallias, though their sori appear in the mature state to be much further intramarginal than they are in Davallia. The latter of these genera has not been examined developmentally. But in Nephrolepis biserrata, (Sw.) Schott, the matter has been investigated, though, owing to certain technical difficulties, the development has not been fully followed. Fig. 25 shows a comparatively early stage of the sorus, which clearly corresponds in essentials to that of Davallia, but the inequality of the two lips is here so strongly marked as to make it a still more open question whether or not the receptacle itself originated in a marginal position. It may be held that the lip $(l)$, in Fig. 24, of Davallia is the phyletic counterpart of the body marked $(l)$, in Fig. 25, of Nephrolepis, which is often described as the 'indusium'. The hollow behind it is the receptacle. The large body marked $(u)$ in Fig. 25, which appears as a continuation of the leaf-surface, is the correlative of the upper lip $(u)$ in the Davallia. The difference between the two sori appears to lie in the much greater inequality of development of the two sides in Nephrolepis, and especially in the very extended development of the upper lip (u). In the Davallia this soon loses its marginal segmentation, and its greater part results from intercalary activity. But in Nephrolepis, as is shown by Fig. ${ }^{25}$, an active marginal segmentation appears to account for the predominance of the upper lip. It must remain for the present uncertain whether or not this activity was developmentally continuous with that at the margin of the pinna before the sorus appeared. If that were shown to have been the case, it would indicate that there had been a sort of 'phyletic slide' of the originally marginal sorus to the lower surface of the pinna. That such a transition can occur will be shown in the next memoir of this series, which will deal with the Blechnineae, and it may be hoped that before long such questions will be set at rest for the Ferns now under consideration by a careful comparative study of the development of their sori. Meanwhile, 
the cursory observations now made indicate that in all these Ferns the sorus is phyletically marginal in origin, but that the more advanced types may show a shifting of the sorus towards the lower surface. The biological significance of this is obvious, for protection of the young sorus is thereby secured, and this consideration therefore supports the view here advanced.

Three lines of argument should be used in arriving at such a conclusion as that above stated. First, the comparative use of detailed observations which form the immediate foundation upon which it may be based, by providing intermediate steps from the originally marginal state to the superficial. It is admitted that the series here given is an incomplete one, and that the whole question will have to be gone over again, and tested by numerous examples. The second line of argument is that based on the comparisons and conclusions of the systematists, chiefly relating to external characters, upon which the current grouping has been based. The probability is that such conclusions are correct. The third is the argument from physiological probability. In the present case, these three lines of evidence coincide in support of the conclusion as stated. Accordingly, the proper place of Nephrolepis (and probably also of Oleandra) in a phyletic system should be in near relation to Saccoloma and Davallia, notwithstanding the position of the sorus on the lower surface of the leaf. But their place in the system will be more distal than those genera where the sorus is more nearly marginal.

The similarity in position of the sorus, and in form of the indusium between Nephrolepis and the Aspidieae, is very striking. Commonly, there is this difference between Ferns of the Davalloid and those of the Aspidioid affinity: that where the sorus is 'phyletically' marginal the vein terminates in its receptacle, while, where it has been 'phyletically' superficial, the sorus is seated on a vein which still continues its course. But this does not appear to be a perfectly dependable rule. Any exceptions to it would still further accentuate the striking parallelism which these Ferns show. But, nevertheless, it must be concluded that the two groups have been distinct in their descent. The one is essentially marginal, the other essentially superficial, in the position of the sori. They illustrate in a remarkable degree the convergent development of two distinct phyletic lines.

\section{LOXSOMA.}

This Fern, as interesting as it is enigmatical in its relationships, has again come into prominence through a recent paper by Professor von Goebel ('Flora,' I9I 2, Band cv, p. 33, \&c.). He has there not only figured the sorus afresh, but also described the prothallus, hitherto unknown. After a general survey of the known characters of Loxsoma, he concludes (p. 45) that there is no ground for placing Gleichenia in near relation with Loxsoma, and that the same holds for the Hymenophyllaceae. He considers that it 
is more nearly related to the Cyatheaceae than to Gleicheniaceae: he suggests that it is a reduced form as regards its sporangium, and especially that the annulus, with its well-known incomplete induration, is a derivative from the type of the Cyatheaceae. His discovery of stiff appendages ('Borsten') upon the older prothalli provides a line of parallel comparison, for such 'Borsten' occur also on the prothalli of the Cyatheaceae. While welcoming the facts which von Goebel has added, I regret not being able to accept his conclusion, and I shall here re-state an alternative opinion, already expressed elsewhere ('Land Flora,' pp. $57 \mathrm{I}-4$ ).

It is an unfortunate circumstance that the term 'Cyatheaceae' has been used in a more extended, as well as in a restricted, sense. Diels (Engler u. Prantl, i. 4, p. I I3), Christ ('Farnkräuter,' p. Io), and Christensen ('Index Filicum,' p. xvi.) have all applied it in the more extended sense, so as to include the Dicksonieae, the Thyrsopterideae, and the Cyatheae (or Alsophileae)-that is, to comprise Gradate Ferns, some with marginal, some with superficial sori. But Hooker, in the 'Synopsis Filicum' (pp. 9 and I5), separated his Tribe I, Cyatheae, from his Tribe II, Dicksonieae. Though he thus separated the main genera of Cyatheoids from the Dicksonioids, he placed the marginal Thyrsopteris with the superficial Cyatheae, and such superficial genera as Onoclea and Hypoderris with the marginal Dicksonieae. So that still in his system the position of the sori was not given its proper diagnostic importance. It will be pointed out later that it is essential to keep the distinction between marginal and superficial sori clearly in view, if a truly phyletic classification is to be arrived at : and, if that be so, clearly the relation of Loxsoma will be with the Schizaeaceae on the one hand, and with the Dicksonieae on the other, rather than with the Gleicheniaceae or the Cyatheae in the restricted sense.

Professor von Goebel demonstrates the presence of 'Borsten' on flattened prothallus of Loxsoma. They resemble structurally the stiff dark hairs which cover the rhizome of that Fern. He points out that their presence on the prothallus is a characteristic of the Cyatheaceae in the widest sense, and of some few Polypodiaceae, and that they are recorded from no representative of the Gleicheniaceae or Schizaeaceae. In his 'Organographie' (p. 4I2) he records that these hairs are present in Balantium antarcticum, so that they are not diagnostic between the marginal series (Dicksonieae) and the superficial (Cyatheae). The fact that they are present in Loxsoma may therefore be held as confirming a relationship with the marginal series, viz. with the Dicksonieae. But, on the other hand, the fact that they are absent from the prothalli of the Gleicheniaceae and Schizaeaceae, as also from those of the Osmundaceae, must not be held in any way to preclude comparisons with those relatively primitive types in respect of other characters, and particularly of those of the sorus and sporangium. 
The sorus of Loxsoma is marginal in origin, with a cup-shaped indusium, from the centre of which the receptacle springs. Upon it the sporangia arise in a basipetal sequence. The position and structure of the sorus correspond to what is seen in Thyrsopteris, but the sporangia of Loxsoma differ in having an oblique, though imperfectly indurated annulus, and their dehiscence in a median plane. I have made new drawings of the sporangia from three different aspects. Fig. 26, $a$, shows a sporangium with its attendant hairs presenting its 'peripheral' face; that is, the side which is away from the receptacle. The annulus is seen with its distal side composed of large indurated cells, while the slit of dehiscence lies in the median plane. The basal side of the annulus is not indurated, though the sequence of its cells is easily traced, and sometimes they show a partial induration. The tabular cells which lie within the ring constitute the 'peripheral' face of the sporangium, and they are seen to be numerous. Fig. $26, b$, shows the same sporangium from the opposite side, i. e. it represents the 'central' face, which is turned towards the receptacle. It is composed entirely of thinwalled tabular cells, and the annulus is wholly out of sight. Fig. 26, c, shows a similar sporangium seen laterally, and it brings out the conical form which the sporangium usually shows. The apex of the cone is at the centre of the 'peripheral' face. The biological meaning of the imperfectly indurated annulus was explained in my Studies, IV, Leptosporangiate Ferns ('Phil. Trans.,' vol. cxcii, p. 49). The comparative conclusion there arrived at was that Loxsoma appears to be a link connecting the GleicheniaSchizaea affinity with the Dennstaedtiinae. As Professor von Goebel has now suggested that Loxsoma is a reduced type from the Cyatheaceae, and rejects the comparison with the Gleicheniaceae, I take this opportunity of re-stating my position in the matter.

In my view the underlying type of sporangium is the same in all Ferns which show an oblique annulus. Especially is this the case for the Gleicheniaceae and Schizaeaceae, as was fully shown in my Studies, IV, on Leptosporangiate Ferns ('Phil. Trans., vol. cxcii, p. IOI). In all of them a 'peripheral' is distinguished from a 'central' face, and in all the more primitive types, where the sorus is not monangial, the position of these faces relatively to the receptacle is that which the above terms imply. The differences lie, not as von Goebel's diagram ('Flora,' vol.cv, p. 4I, Fig. 7) would suggest, in the position of the ring, but in the greater or less proportions of the two faces. I would point out that in von Goebel's Fig. 7 (1. c., p. 4I), which is here reproduced as Fig. 27, while in (I) the orientation of the sporangium of Loxsoma is quite correctly given relatively to the receptacle of the sorus, in his diagram (II) of Gleichenia the receptacle is omitted, and the orientation of the sporangium relatively to the leaf-surface is shown, which is quite a different thing. I venture to amend his diagram in Fig. 27 bis by putting in the receptacle, and turning it into a position corresponding to that of the 
Fig. $27, \mathrm{I}$, and adding a sporangium facing the first, so as to show what is actually seen in Gl. fabellata or any of the Mertensia section. It will then be seen that the annulus in Fig. $27, \mathrm{I}$, and in the right-hand sporangium of Fig. 27 bis, is in the same position relative to the receptacle ( $p l$.$) , and that$ is the proper basis for the comparison.

But the point which is the most striking in the sporangium of Loxsoma, as compared with that of any other Gradate Fern, is the median dehiscence. The median dehiscence is, however, the rule in the Simplices, such as the Schizaeaceae and Gleicheniaceae. The question will then be whether or not it is probable that this character of Loxsoma is a survival from some simpler type of Ferns. Professor von Goebel's opinion is that it is not a survival, but a secondary acquired condition, derived from some Cyatheaceous source. Against this it may be urged that no such modification of the Cyatheaceous type is known elsewhere; nor does it seem probable, for it would, in fact, be a reversal of such a progression as we have reason to believe has actually taken place, having been determined by the mechanical requirements of the gradate sorus. The case made out in No. II of these Studies ('Ann. of Bot.,' vol. xxvi, p. 3II) for a probable progression from the Gleicheniaceous type, through Lophosoria to the Cyatheaceous type, involves a transition from a simple to a gradate sorus, together with a change from a median to a lateral dehiscence. Similarly, I suggest that in the Schizaeaceae, Loxsoma, and the Dicksonieae there has been a progression from simple (marginal) to a gradate sorus, and from a median to a lateral dehiscence. But, in the case of Loxsoma the two changes have not synchronized. While it has acquired the gradate sorus, it has retained the median dehiscence characteristic of the living Schizaeaceae. In these latter Ferns, the stomium is not of an elaborate type, as shown by Prantl's figures ('Schizaeaceen,' Pl. V, Fig. 8I ; Pl. VI, Fig. 98 ; Pl. VII, Fig. I04; Pl. VIII, Fig. I4I). In all of the four genera the split appears as little more than an interruption of the continuity of the indurated ring, without a definitely constructed stomium such as is seen in the Cyatheaceae; and this is what is the state in Loxsoma. Further, the form of the sporangium of Loxsoma resembles markedly that of Lygodium, though the lopsidedness is not so extreme (cf. Fig. 26, c, with Prantl's figure of Lygodium, 1. c., P1. VI, Fig. 97). But the annulus in Loxsoma is a wider ring, as, in point of fact, it is in Aneimia also, and the 'peripheral' face larger as a consequence. On the other hand, the spore output is only sixty-four, as against the larger numbers of the Schizaeaceae, though the form of the spores is similar. The general conclusion is, then, that there is a substantial similarity of the sporangia of Loxsoma to those of the Schizaeaceae, though not to any one genus of that family. If this be a true comparison, then we may look on Loxsoma as a Fern having, like the Schizaeaceae, a marginal origin of the spore-bearing members, and as having progressed to the state of a gradate sorus, but 
retained the median dehiscence with modifications which are peculiar to itself. In fact it exhibits a state transitional between a Schizaeaceous and a Dicksonioid type. Such a progression would in the peripheral series of Ferns run parallel to that seen in the superficial series, as exemplified by Gleicheniaceae, Lophosoria, and the Cyatheoids.

Other lines of comparison accord with this conclusion. The dermal appendages on the rhizome of Loxsoma are stiff brown bristles ('Borsten '), with longitudinal, as well as transverse, septation towards the base. They resemble the stiff brown bristles of Thyrsopteris. But flattened ramenta, which are so marked a feature in the Cyatheae, are absent in both. The solenostelic structure described in detail by Gwynne-Vaughan ('Ann. of Bot.,' vol. $\mathrm{xv}, \mathrm{p} .7 \mathrm{I}$ ) corresponds to what is seen in many relatively primitive Ferns. It may, however, be specially noted that it is characteristic of the creeping Aneimias of the section Aneimiorrhiza (cf. Boodle, 'Ann. of Bot.,' vol. xiv, p. 359). The undivided leaf-trace of Loxsoma, in particular, has been compared by Gwynne-Vaughan with that of the Dennstaedtiinae on the one hand, and with that of Aneimia on the other. But, as regards the Cyatheaceae in the widest sense, to which von Goebel would refer Loxsoma, it may be remarked that in them the tendency is to subdivision of the leaftrace, extending in Cibotium and in Cyathea to the extreme leaf-base. In Loxsoma, however, the leaf-trace is undivided, and continues upwards in that condition, as it does also in Aneimia. Thus, the rough vascular structure would indicate a nearer similarity to the Schizaeaceae than to the Cyatheaceae in the widest sense. Accordingly, in attempting to place Loxsoma phyletically, it should, in my opinion, be regarded as the sole representative of a distinct tribe; and its position appears to lie about the limit between the Simplices and Gradatae. And as its sorus is marginal, it takes its place in the marginal series, between the Schizaeaceae and the Dicksonia-Dennstaedtia series. It may be held generally to be an up-grade type, though the biological requirements of the sorus have led to a reduction of one side of the annulus.

A fossil referable to a somewhat similar position has recently been described by H. H. Thomas (Stachypteris Halli, a new Jurassic Fern, 'Proc. Camb. Phil. Soc.,' vol. xvi, p. 610), in which spike-like marginal sori are found. There is some uncertainty as to the details of its sorus, but sufficient is known to countenance its reference also to an intermediate position between Schizaeaceae and the Dicksonioids, somewhat similar to that now ascribed to Loxsoma.

\section{On the Phyletic Value of Soral Position}

A considerable number of relatively primitive Ferns have been discussed in the above pages, chiefly as regards their external morphology, their coarse anatomy, and their soral condition. They fall into two $\mathrm{K} \mathrm{k}$ 
sequences, viz. (I) those with their sori superficial, and (2) those with a marginal position of the sori. The latter are characterized by the factnow demonstrated for Thyrsopteris ('Phil. Trans.,' vol. cxcii, p. 67), Cibotium, Saccoloma, Odontoloma, Davallia, and Lindsaya-that the receptacle originates from the actual margin, while the marginal initials appear themselves to give rise in certain cases to the earliest sporangia. A similar condition was long ago demonstrated by Prantl for the Hymenophyllaceae ('Die Hymenophyllaceen,' I875, Taf. V), and shown by him to hold with singular constancy in the Schizaeaceae ('Die Schizaeaceen,' I 88 I, pp. 39-46), while Loxsoma appears also to share this character. These groups of Ferns, which show natural relationship in other features also, so that they have habitually been ranked together, constitute a great series characterized by having their sori marginal.

In a second great series the sori are as constantly superficial, having in their origin no direct relation to the margin of the leaf. They include the Gleicheniaceae, Matonineae, Metaxya, Lophosoria, and the Cyatheae, with their related or derivative forms, such as the Woodsieae, Struthiopteris, and Onoclea, Peranema, and Diacalpe, the Nephrodieae, and their derivatives and relative forms. Also Plagiogyria, and the related Pterideae on the one hand, and the Blechneae on the other, are all, strictly speaking, types with sori of superficial origin. However nearly these may approach the margin of the fertile pinnae, in no case have they been shown to be actually derived from it. Indeed, to describe the sori of any of these Ferns as marginal is not in accordance with the observed developmental facts. In all cases their sori arise superficially from the flattened surface of the leaf.

The value of the distinction upon which this grouping is based as a phyletic criterion will depend upon its constancy. In the series with the sori superficial the constancy of that feature is believed to be absolute, with the exception of certain anomalous cases to be noted below. But the same cannot be said for the series which has the sori typically marginal. It will be necessary to look into this matter in detail. At the outset it would appear to be biologically a natural and advantageous adjustment that the sorus, if actually marginal, should be deflected for purposes of protection towards the lower surface of the leaf. It will be seen that this has repeatedly happened. But it will be shown that comparative reasons indicate these changes as secondary and biologically adaptive.

Looking back to the most primitive living types of Ferns, the Eusporangiatae, it is evident that the Ophioglossaceae have typically the marginal position of their spore-bearing members; also, that the Marattiaceae bear as typically their sori upon the leaf-surface. But the Osmundaceae, which in so many features occupy a position at the very base of the Leptosporangiate Series, are as a family indeterminate in this respect. Moreover, their sporangia are not disposed in definite sori. In Osmunda the sporangia 
are in serried ranks which are essentially marginal, though they may spread on to the surfaces. In Todea they are seated on the lower surface. The Osmundaceae are, however, the only living family which shows this indefiniteness. Certain isolated exceptions occur elsewhere, but no other whole family is characterized thus. All are either characteristically marginal or superficial. It may be held from these facts that while the Eusporangiate families had already resolved this question of the position of their spore-bearing organs relatively to the leaf-margin, the Osmundaceae represent a very ancient type of Leptosporangiate Ferns in which the question was still undecided. This family may in fact in some sense suggest, or even represent, the indeterminate ancestry from which the Leptosporangiate Ferns, with their two distinct sequences, the marginal and the superficial, originally sprang.

We have seen that the superficial position of the sori is, with certain exceptions, constant in those Ferns which have adopted it. The exceptions must be considered in their bearing upon the constancy of such characters for phyletic comparison. Examples are found in Polystichum aculeatum, (L.) Schott, var. 37, anomalum, Hk. \& Arn., and certain aberrant forms of Scolopendrium vulgare. The former of these is a variety of $P$. aculeatum, which grows on the Horton Plains, Ceylon, and was described in $185^{6}$ by Hooker and Arnott. The peculiarity consists in the appearance of the sori ' usually on the superior face'. Hooker states ('Sp. Fil.,' iv, p. 27) that 'the species is in cultivation at Kew, and retains its usual peculiarity of bearing the sori on the upper or anterior side of the frond'. Here it would appear that there has been in some way a transference of the stimulus, whatever it be, to sorus-formation to a spot where it is not typically present; for the sori themselves appear to be quite normal, except for their position. A somewhat similar state, though accompanied by malformation of the leaf, is to be found in some of the extravagant monstrous forms of Scolopendrium vulgare. Such cases, however, do not appear to me to throw any satisfactory light on the phyletic story. They may serve some time as points of attack on the question what it is that determines soral development at all. But the very suddenness of their appearance and the isolation of their occurrence stamps them as anomalies, rather than as dependable phyletic signs.

Very much the same may be said of the occasional occurrence of the sori in Deparia Moorei superficially. In the species $D$. prolifera they appear to be as a rule marginal, though in some Sandwich Island specimens they incline to the lower surface, as in Davallia. ${ }^{1}$ A marginal position is the rule also in D. Moorei; but isolated sori are found not uncommonly upon the upper surface, and even at a distance from the margin. The absence of intermediate steps in D. Moorei suggests again an anomalous transfer of the stimulus to soral formation in the young primordium, rather

1 Compare Mettenius, Farngattungen, vi, p. 63 , and Pl. VI, Figs. I 7-20.

$\mathrm{K} \mathrm{k} 2$ 
than any significant fact for morphological comparison in Ferns at large. Such cases as these are few and isolated, so that they do not appear to indicate any stable modification of the usual marginal arrangement.

But quite a different view must be taken of that gradual and very general modification of position of the sorus which is seen in the derivatives of the Dicksonioid series. Here, with the sori typically marginal in origin, as they are now demonstrated to be in Thyrsopteris, Cibotium, Saccoloma, Odontoloma, and Davallia, there is seen to be a phyletic drift towards a position of the sorus upon the lower surface. It is probably a biological adaptation by which better protection is secured. But even in cases where the indusial lips have become very diverse in size and structure, the 'upper' having grown to all appearance like a continuation of the foliar expanse, still the receptacle is as truly marginal in origin as in the types where both lips are practically equal. It is thus clear that in these facts there is nothing to detract from the importance of the marginal position in its phyletic aspect. All that we see is a biological adaptation which tends to mask the original position of the sorus on the margin of the leaf.

The converse, viz. the approach of the sori to the marginal position in certain Ferns where they are typically superficial, is seen in the Pterideae. In simple cases, such as Plagiogyria and Adiantum, it is quite obvious that these are merely special cases of the location of superficial sori near to the margin. The consequence is, however, that a curious convergent phylesis has occurred; so that the appearance of some truly marginal types, such as Lindsaya, is very closely similar to that of some superficial types, such as Pteris. It may, indeed, be the case that sometimes the line of demarcation has not been rightly drawn. Developmental evidence from the earliest stages will have to decide in questionable cases.

An almost equivalent convergence is seen between the Aspidieae, which arose from a superficial origin, and such genera as Nephrolepis and Oleandra, the origin of which appears to have been from marginal types. Here, again, it is upon a basis of observation of the earliest stages of development of the sori, combined with wide comparison by other criteria, that it may be possible to allocate such converging types to their respective phyletic sources.

But the Davallieae, the Pterideae, and the Aspidieae are all relatively advanced types. None of the Ferns quoted as showing this convergence are really primitive. It follows that, notwithstanding such instances of convergence, and notwithstanding the modifications from type, sudden or gradual, such as have been above mentioned, a great body of fact establishes this conclusion: That from a very early period the Leptosporangiate Ferns have progressed along two parallel lines, the one characterized by a marginal, the other by a superficial position of the sporc-bearing organs; and that these lines have remained phyletically distinct throughout. 
If the course of events has really been as thus sketched, and the distinctness of the two phyla be as stated above, it will be apparent that in the phyletic treatment of Ferns the criterion of position of the sorus must take precedence, in point of early appearance and of constancy, over several others to which importance has habitually been attached. For instance, all the stelar types may be illustrated in either of these sequences; also all the three conditions of the sorus, simple, gradate, and mixed. The size and spore-output of the sporangium vary through a wide range in each. In each the more primitive types show hairs, while scales appear in the more advanced. Various minor characters also fluctuate within the series named. In fact, excepting the most fundamental features of the protostele and of the sporangium itself, there is no character so deeply seated in point of early appearance and constancy as the position of the spore-bearing members relatively to the leaf-margin. Accordingly, in the systematic treatment of the Filicales full weight should be given to it. The Leptosporangiate Ferns (exclusive of the indeterminate Osmundaceae) will then be naturally divided into two sequences which may be fitly styled the Leptosporangiatae Marginales and the Leptosporangiatae Superficiales. And the grouping of the families will be tentatively thus :

Marginales.

Simplices. $\{$ Schizaeaceae

Gradatae. $\left\{\begin{array}{l}\text { Loxsomaceae } \\ \text { Hymenophyllaceae } \\ \text { Dicksonieae } \\ \text { Thyrsopterideae }\end{array}\right.$

Mixtae. $\left\{\begin{array}{l}\text { Davallieae } \\ \text { Oleandreae }\end{array}\right.$
Superficiales.

Gleicheniaceae

Matoniaceae

Cyatheae

Woodsieae

Onocleinae
Aspidieae
Blechninae
Asplenieae
Pterideae

The above table does not attempt to indicate phyletic sequences with accuracy or completeness. It is constructed merely to show the main constituents of the two great series. Moreover, certain large groups are intentionally omitted, such as the Polypodiinae and Acrostichinae, the Vittarieae and Taenitidinae, since it is quite uncertain how these will have to be split up and phyletically grouped, until much further detailed work has been done upon them. It is seen that in both the series there are representatives of the three soral conditions. But the lines of limitation of these cut athwart the two main series ; in fact, the distinctions which they 
embody do not lead to a phyletic classification, which should be the end ultimately to be aimed at. They represent merely 'states' which may be transitional or final in any phyletic sequence. It will be apparent at once that the grouping according to the original position of the sorus, since it is based upon a very early and a very constant distinction, is phyletically of greater value than any grouping based on features less constant and later in appearance. And this seems to be the true character of the distinction between Simplices, Gradatae, and Mixtae. That they are 'states' passed through in distinct phyletic lines was fully realized when these distinctions were first drawn ('Phil. Trans.,' vol. cxcii, p. I23). The three divisions were then held to 'illustrate three steps in the evolution of the sporophyte in the Order'. Moreover it was clearly stated that 'the members of each category are not to be taken as necessarily of common descent, but are grouped according to common adaptation'.

The same may, I think, be said of Professor von Goebel's recent suggestion to recognize two groups of Leptosporangiate Ferns as constituted from related forms (Archegoniatenstudien, xiv, 'Flora,' Bd. I05, p. 5I, I9I2). Of the Filices Leptosporangiatae he distinguishes as Group I, Sporangiis longicidis (the sporangium opening by a longitudinal slit), the Osmundaceae, Schizaeaceae, and the Gleicheniaceae. As Group II, Sporangiis brevicidis (the sporangium opening by an oblique or transverse slit), the Cyatheaceae, Hymenophyllaceae, and Polypodiaceae. This distinction seems to me to suffer under the same disability as that of the Simplices, Gradatae, and Mixtae, in that it also cuts athwart the lines based on the earlier and more constant character of soral position; while in itself it is based on a circumstance which can be explained as a concomitant, or it might even be held merely as a mechanical consequence of the arrangement of the sporangia in the sorus.

The objection to either of these methods of segregation of Leptosporangiate Ferns is in essence the same as that which opposes the suggestion of Kühn to classify the Polypodiaceae according to the nature of their dermal appendages. But they have the advantage in dealing with parts, the sporangia, which are of greater importance than the hairs : and it was the hairs which Kühn took as the foundation of his method (Die Gruppe der Chaetopterides unter den Polypodiaceen, 'Festschrift zu dem Jubiläum der K. Realschule zu Berlin,' 1882). Here again a character which is now known to have changed in a number of distinct progressive lines had been selected. We now know that the segregation of these lines is founded on characters anterior to, and more constant than, the distinction of those types of the dermal appendages which he used.

For the reasons thus stated, I find myself unable to accept Professor von Goebel's suggested partition of the Leptosporangiate Ferns. The partition according to the original position of the sorus appears to me 
to have the advantage in leading towards a truly phyletic classification, since it is based upon a very early and remarkably constant character.

Returning in conclusion to the genus Metaxya, we may consider its position in the scheme thus sketched. It is clearly one of the Superficiales, and its near relation to the Cyatheae, which has always been recognized, is indisputable. But it shares with Lophosoria the distinction of standing aloof from them. It is more primitive than they in several important characters, such as the creeping habit, the presence of hairs and absence of ramenta, the simple solenostelic axis and undivided leaf-trace, the simultaneous sorus and almost vertical, interrupted annulus. Like Lophosoria it is technically one of the Simplices, and the other characters named as primitive will justify its being placed in the superficial series below any of the true Cyatheae. Its relation is probably nearest to certain species of Alsophila with hairy sori. But until these species have been more exactly examined the degree of that relationship cannot be defined.

The question, however, remains what relation, if any, there is between Metaxya and Ferns other than the Cyatheae. It cannot escape notice that several of the early writers named it Polypodium ( $P$. rostratum, Willd., P. Humboldtii, Poir., P. blechnoides, Sw.). A similarity may certainly be traced in general external characters, such as the creeping habit, the simple pinnation, and the flat hairy sori, to various types of Polypodium, and especially to the Phymatodes section of the genus. But they differ in the scaly dermal coverings, the high degree of subdivision of the vascular tracts in both leaf and axis, and in their mixed sorus. An apparent similarity of habit to Neocheiropteris palmatopedata, (Bak.) Christ, that remarkable Fern from Southern China, suggested an examination of its characters, as possibly supplying some intermediate or explanatory condition. But this anticipation was not realized. Text-fig. B shows a series of transverse sections of the rhizome of that Fern at the insertion of a leaf. The vascular system is seen to resemble other Polypodiaceous types in showing in the axis a large number of small meristeles disposed in a ring, while the leaf-trace also consists of a large number of small strands. The disposition of these is, however, along lines similar to those of the solenostele and the undivided leaf-trace of Metaxya, but both vascular tracts have been broken up by numerous 'perforations'. It is, however, worthy of note that occasionally such 'perforations' are seen in Metaxya (compare Fig. 3, v), so that the difference in this respect is only one of degree. ${ }^{1}$ Scales are present in Neocheiropteris

1 Since the above was written, Professor Gwynne-Vaughan has quoted to me a considerable number of instances among Ferns ranked under the comprehensive name of Polypodium, where the subdivision of the meristeles by perforations is in abeyance or less complete than in Neocheiropteris. It would be going too far afield to extend the present observations in this direction, and doubtless he will make his own statement on the point. But meanwhile the fact that such states occur is evidence of the correctness of the view put forward in the text. 
as a dermal covering. The sori resemble those of Metaxya in their large area and in their position, and in the presence of numerous hairs scattered among the sporangia. But the latter have thin and long stalks and an interrupted annulus, while the sorus appears to be of the mixed type.

Notwithstanding that Neocheiropteris does not provide so convincing a link of connexion as was anticipated, the opinion may still be held, and its validity tested by further observations, that there is a natural relation between Neocheiropteris or Phymatodes and Metaxya. A Fern modelled on the Metaxya-type with numerous perforations in the stele and leaf-trace, with scales in place of simple hairs, and with a mixed sorus and longstalked sporangia with a vertical annulus, would inevitably be classed as
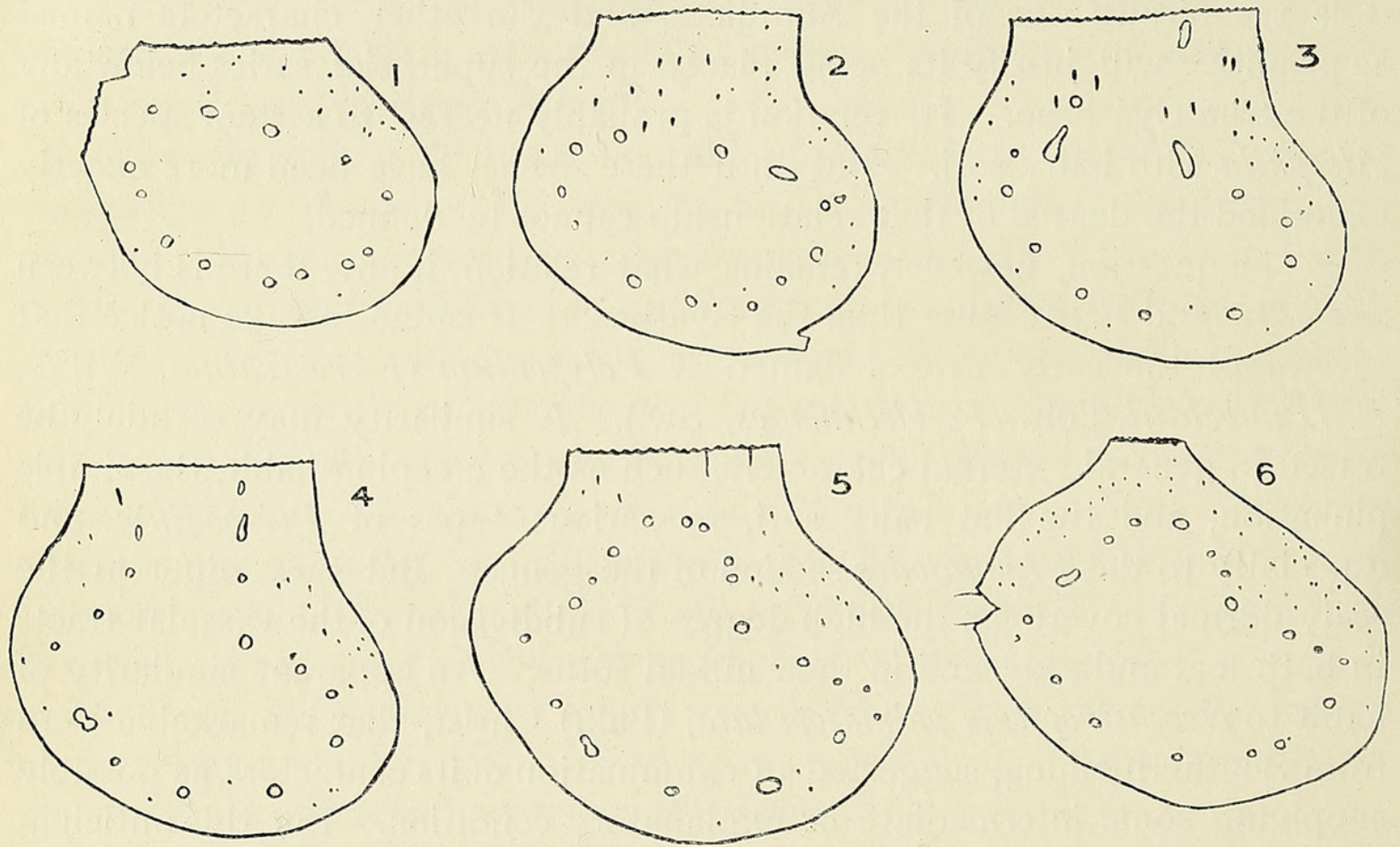

TEXT-FIG. B.

a Polypodium. But all these would be natural progressive steps from the condition of Metaxya, such as are abundantly illustrated elsewhere. There is reason to believe that they may have been taken by forms derivative from the Metaxya-type. But so far we have succeeded in recognizing no intermediate forms which would link Metaxya definitely with such Polypodioid derivatives. Till the gap is closed by such links, the suggested relation cannot count as more than a working hypothesis. But it is an hypothesis which should stimulate further inquiry.

\section{SumMARY.}

I. Metaxya rostrata, Presl, which has currently been included in the genus Alsophila, as A. blechnoides, (Rich) Hk., should be retained as Presl placed it, viz. as the single species of a substantive genus. 
2. The characters which distinguish it from Alsophila are the creeping habit, the unbranched hairs and absence of scales, the solenostelic structure of the axis and undivided leaf-trace, the flat receptacle and simultaneous origin of the numerous sporangia, and the almost vertical annulus, interrupted at the insertion of the sporangial stalk.

3. These characters collectively place it in a position phyletically more primitive than the true Cyatheae, in a somewhat similar independent position to that held by Lophosoria.

4. Notwithstanding the dictyostelic structure with medullary strands shown in their upright axes, all the genera of the true Cyatheae may at times show a solenostelic structure in their runners, which arise from dorsal buds, as in Lophosoria and Metaxya.

5. Thyrsopteris shows a solenostelic structure of its axis, with a medullary system built up from ' compensation strands'. Its leaf-trace is undivided at the base. This structure closely corresponds to that of Saccoloma.

6. The sori of all such species of Thyrsopteris, Dicksonia, Saccoloma, Odontosoria, Lindsaya, and Davallia as have been examined developmentally arise from the actual leaf-margin, their indusia being of the nature of surface growths.

7. The sori are quite separate in Thyrsopteris and Dicksonia: but they have their upper indusial flaps fused laterally in Saccoloma; both flaps are fused, and their receptacles also in Lindsaya, while a vascular commissure may join the distal ends of the veins, which are elsewhere free. These fusions are secondary and derivative characters which indicate phyletic advance.

8. The first sporangia of the sori of the genera named appear to be strictly marginal in their origin, followed by a 'gradate' sequence in the more primitive types, such as Thyrsopteris and Dicksonia, but becoming ' mixed' in more specialized types, such as Lindsaya and Davallia.

9. The sporangia of Thyrsopteris and Dicksonia have a complete oblique annulus, but in the more advanced types it tends to become vertical, and is interrupted at the stalk as in Davallia.

IO. In all the more advanced types, and particularly in Davallia, the sorus, though developmentally marginal, is diverted to the lower surface by the advance in strength and complexity of the upper indusial flap which forms a false margin of the leaf.

I I. This appears to have become accentuated further in Nephrolepis, and probably also in Oleandra, and thus the sori have the appearance of being superficial.

I2. Except for this phyletic slide of the sorus to the lower surface in these relatively advanced types, the sorus is constantly of marginal origin in all the Dicksonioid and Davallioid series, as it is also in Loxsoma, in the Hymenophyllaceae, and in the Schizaeaceae. 
I3. In Loxsoma we see an isolated monotypic genus which has marginal sori like the Schizaeaceae, Thyrsopteris and Dicksonia, and is, like both of them, solenostelic, with hairs as dermal appendages. Its sporangia are of the Schizaeoid type, and retain the dehiscence in the median plane. But the sorus has become gradate as in Thyrsopteris and Dicksonia. Its phyletic position is probably somewhere between, or in relation to, these types.

I4. The Leptosporangiate Ferns (excluding the Osmundaceae which appear in this respect to be indeterminate) fall into two distinct series : the 'Superficiales', in which the origin of the sorus is constantly from the leafsurface, and the 'Marginales', in which it is as constantly from the margin.

I5. So far as the value of the general phyletic characters for the Ferns can be estimated, the criterion of position of the nascent sorus may be held to take precedence, in point of early origin and constancy, over any soral characters except the primal features of the sporangium itself, and over any anatomical characters of the axis derivative from the protostele.

\section{DESCRIPTION OF THE FIGURES IN PLATES XXXII-XXXIV.}

Illustrating Prof. Bower's paper on Metaxya and certain other relatively primitive Ferns.

\section{PLATE XXXII.}

Fig. I. Transverse section of the rhizome of Metaxya, showing the solenostelic structure and coarse superficial hairs. $\times 3$.

Fig. 2. Transverse section of the petiole of Metaxya. $\quad \times 3$.

Fig. 3. I-VI. Successive transverse sections through a rhizome of Metaxya, arranged in basipetal sequence, and traversing the base of a leaf and the young bud which springs from it. For details see the text. $\times 2$.

Fig. 4. Three nearly mature sori of Metaxya, photographed in surface view. Considerably enlarged.

Fig. 5. Vertical section through a young sorus of Metaxya, traversing the vein below it transversely. The receptacle is already of considerable size, and bears hairs, while the numerous young sporangia, all nearly of the same age, are already initiated. $\times 250$.

Fig. 6. Vertical section through a sorus of Metaxya of the same age as the last, but following the course of the vein. The receptacle is here seen to be extended along the vein, and it bears numerous sporangia and hairs. $\times 250$.

Fig. 7. Vertical section of a rather more advanced sorus of Metaxya, showing seven sporangia and numerous hairs. All the sporangia are of nearly the same age. $\quad \times 250$.

Fig. 8. Transverse section through the stalks of sporangia and attendant hairs in Metaxya, showing their relative positions and regular orientation. $\times 25^{\circ}$.

Fig. 9. I-v. Sporangia of Metaxya seen from various points of view. For details see the text. $\times 125$.

\section{PLATE XXXIII.}

Fig. 10. Transverse section of a small runner of Hemitelia setosa, showing the solenostelic structure (sol), with two small medullary strands (m.s.). $\quad s c l=$ sclerenchyma. $\quad \times 2$.

Fig. Ir. Vertical section through the sorus of Dicksonia Scheidei, still sufficiently young to 
show the course of the marginal segmentation, and to demonstrate that the actual marginal cell directly forms the apex of the receptacle of the sorus. The upper $(u)$ and lower $(l)$ indusial flaps arise as superficial, that is intramarginal upgrowths. $\times 250$.

Fig. I2. I-VI. Successive transverse sections of a runner of Cibotium Barometz, from the insertion of the lowest leaf to its extreme base. For details see the text. $\times 2$.

Fig. I3. Photograph of a transverse section at the base of a runner of Cibotium Barometz, showing the 'Lindsaya' condition.

Fig. I4. Transverse section of a petiole of Thyrsopteris elegans. $\times 2$.

Fig. 15. $a, b, c$. Successive transverse sections of a small runner of Thyrsopteris elegans. $a$ is near to the base of insertion, and shows a simple solenostele, with the origin of a root; $b$ is higher up, and a medullary strand is seen within the solenostele; $c$ is again higher, and shows a leaf-trace given off, the leaf-gap nearly closed, with a thickening of the lip preparatory to giving off a compensation strand. $\times 6$.

Fig. I6. $a, b$. Successive stages in the development of a sorus in Saccoloma elegans, showing that the origin of the receptacle is strictly marginal and the individual flaps superficial. It is to be noted that the lower flap $(l)$ takes precedence at first over the upper $(u) . \quad \times 250$.

Fig. I7. $a, b$. Successive stages in the development of a sorus of Odontosoria retusa, showing the marginal origin of the receptacle and the proportions as in Saccoloma. $\quad \times 250$.

Fig. 18. A more advanced stage in the marginal sorus of Odontosoria retusa. $u=$ upper, $l=$ lower indusium. The vascular receptacle bears the oldest sporangium centrally, i. e. it takes the position of the marginal cell, while other sporangia and hairs originate laterally. $\times$ Ioo.

Fig. 19. Transverse section of a sorus of Odontosoria retusa of same age as Fig. I 8 , traversing it in a plane $a, b$, while the plane of Fig. I 8 would correspond to the plane $c, d$. It is seen that the oldest sporangia form a linear series in a median position. $\times 100$.

Fig. I9 bis. Base of sporangium of Odontosoria retusa, showing the oblique annulus with its induration interrupted at the insertion of the stalk. $\times$ I 25.

\section{PLATE XXXIV.}

Fig. 20. A single pinna of Lindsaya lancea, showing the furcate venation, and the sori fused laterally to form an almost continuous, apparently intramarginal series. Both upper and lower indusial flaps confluent, the upper forming the false margin of the pinna. $\quad \times 6$.

Fig. 2I. A small part of the marginal region of a similar pinna, showing an incomplete lateral fusion of the sori, which explains how the Lindsaya sorus was arrived at. To the left is an almost isolated sorus of the Saccoloma type. To the right a more complete fusion is seen, while vascular commissures connect the receptacles laterally. From a drawing by Mr. Thompson. $\times 70$.

Fig. 22. A sporangium of Lindsaya repens, (Bory) Bedd., showing the annulus as a continuous ring, but the induration of its cells is not continued beyond the insertion of the stalk. $\times 250$.

Fig. 23. A vertical section through a very young sorus of Davallia pentaphylla, showing the marginal segmentation leading up to the receptacle, which appears as a valley between the two indusial flaps. As before, the lower $(l)$ takes precedence at first of the upper $(u) . \quad \times 250$.

Fig. 24. A similar section of the sorus of $D$. pentaphylla, but older. The lower indusium $(l)$ has run out to a single layer of cells; the upper (u), which ultimately forms the false margin of the leaf, is more bulky, and shows signs of intercalary activity. The first sporangium occupies a central position on the receptacle, and a later one is seen laterally, thus indicating a gradate sequence. $\times 250$.

Fig. 25. A vertical section of the young sorus of Nephrolepis biserrata, (Sw.) Schott, showing the great inequality of the indusial flaps. The lower $(\iota)$ is markedly intramarginal; the upper $(u)$ appears very definitely as a continuation of the leaf-surface, and has an active marginal segmentation. $\times 250$.

Fig. 26. $a, b$, c. Sporangia of Loxsoma, seen from three different points of view. For details see the text. $\times$ Ioo.

Fig. 27. Photographic reproduction of the diagrams of Professor von Goebel ('Flora', cv, Heft i, p. 4I, Fig. 7). But his diagram (II) has been orientated afresh, in relation to the placenta $(p l)$, and duplicated, so as to show the condition seen in G. fabellata, where, seated upon the leaf lamina, is a sorus, with slightly raised receptacle or placenta $(p l)$, and sporangia on either side of it. This is shown in Fig. 27 bis. 
Annals of Botany

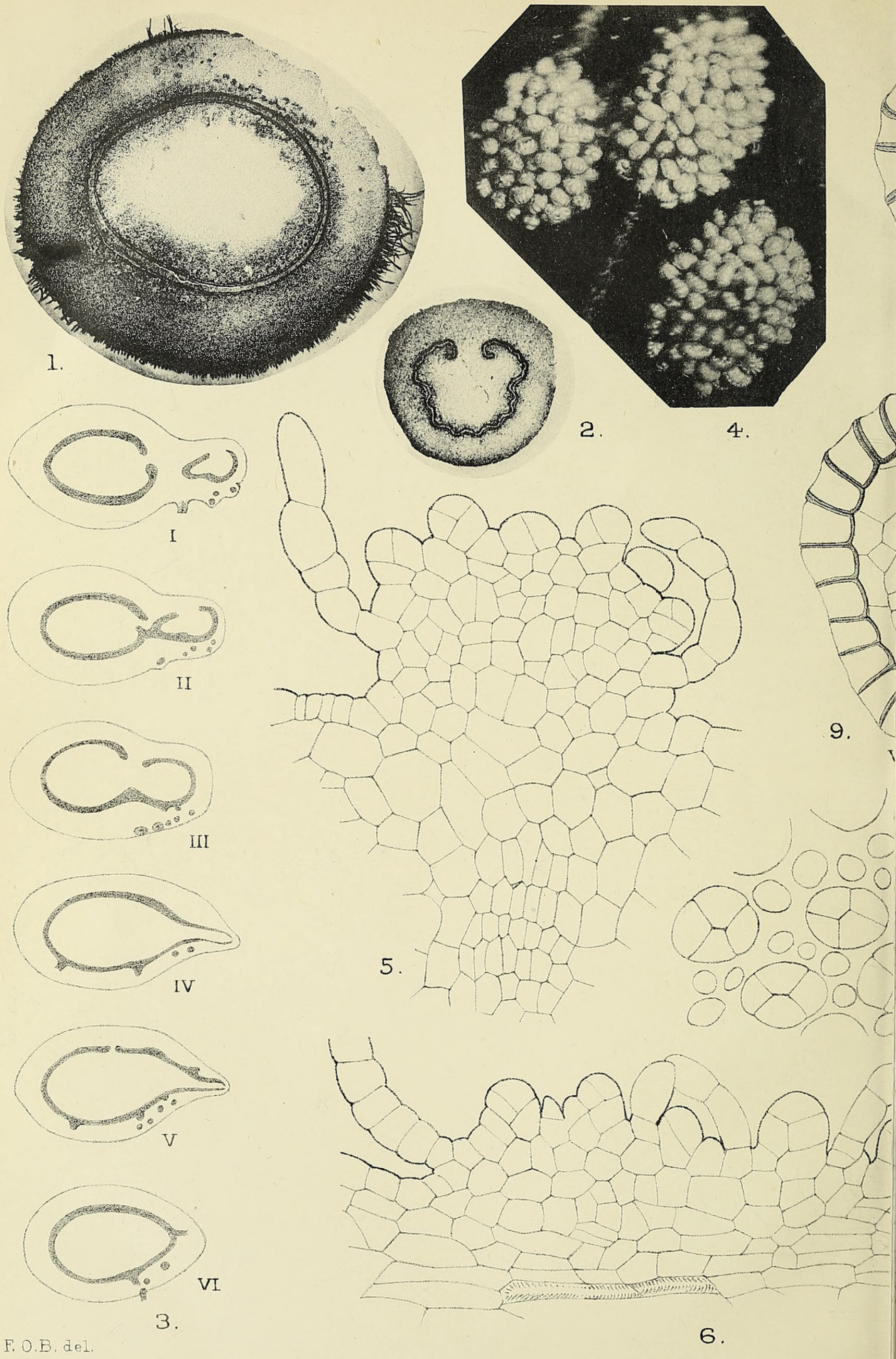

BOWER-METAXYA AND OTHER FERNS. 
Huth lith et imp 


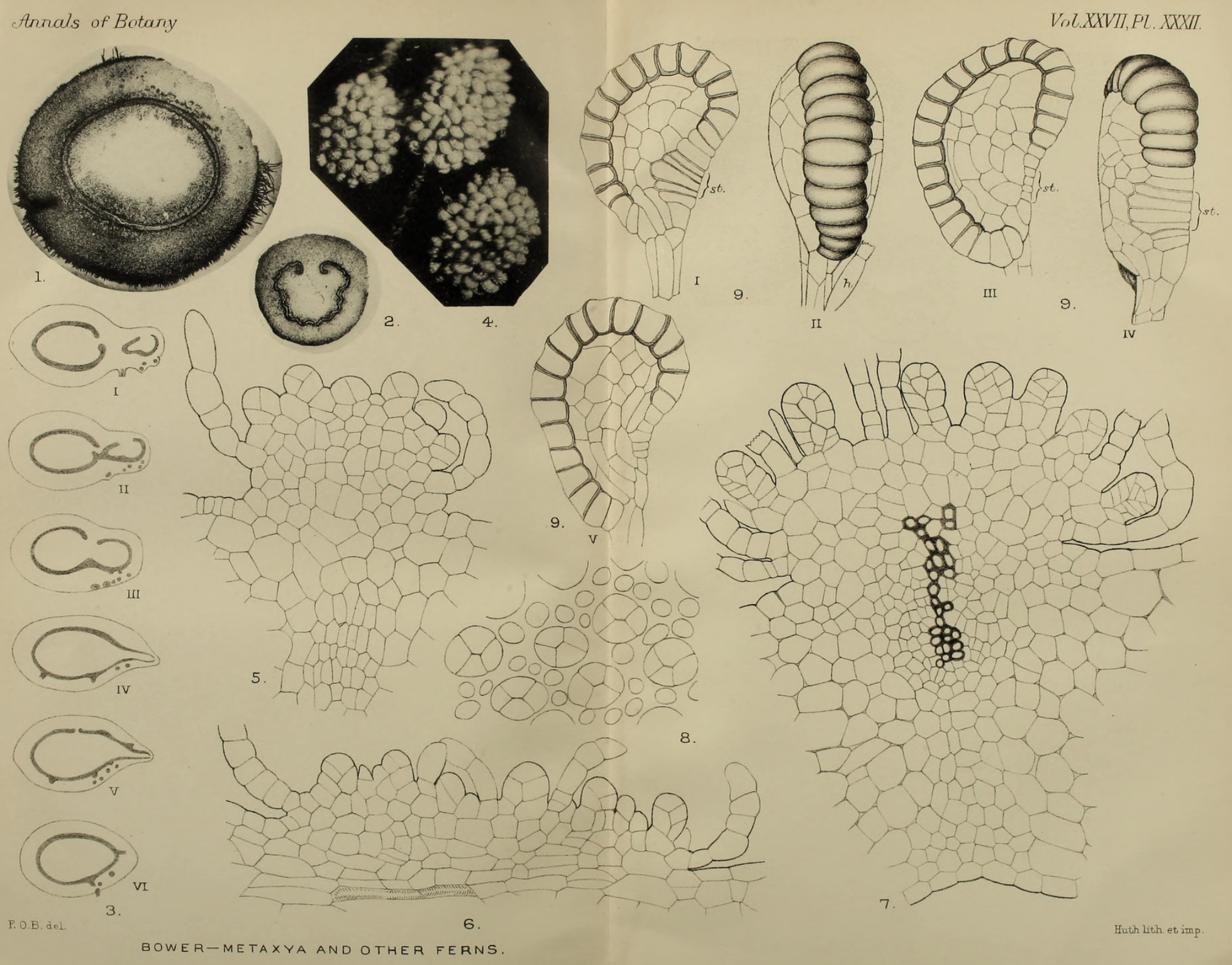


Annals of Botary

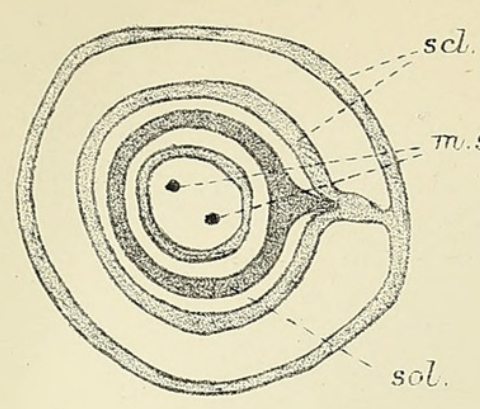

10.
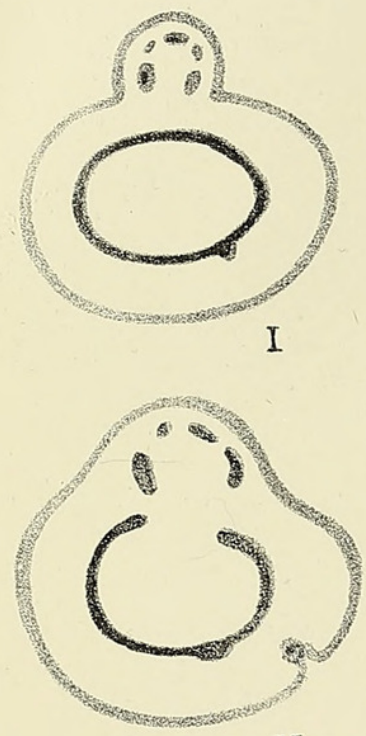

II

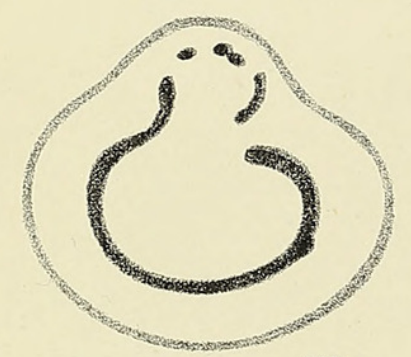

III
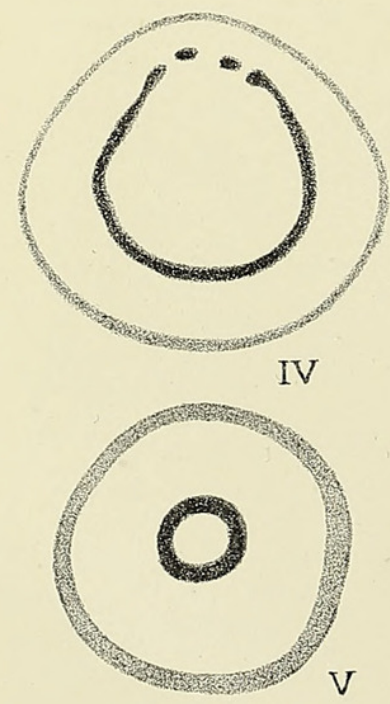

12.

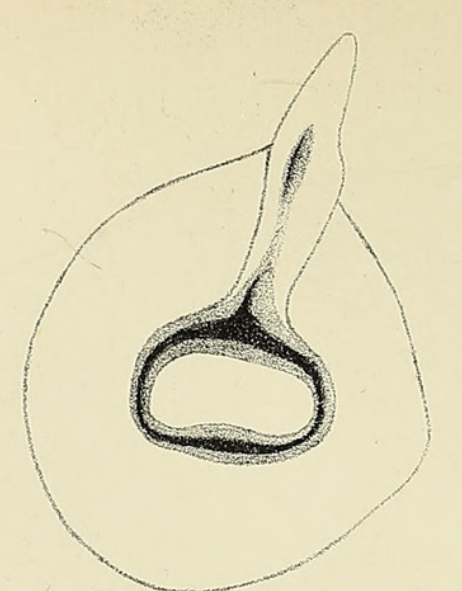

a.

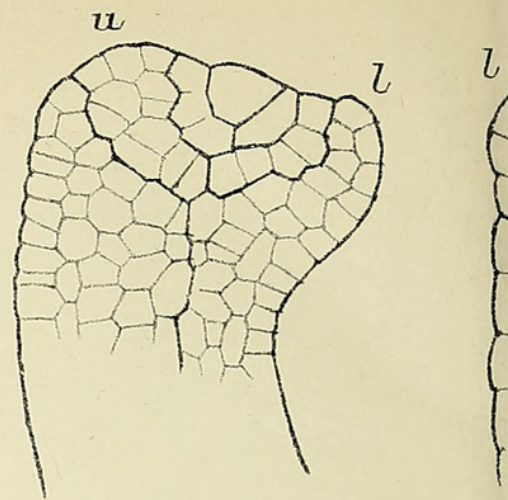

11.
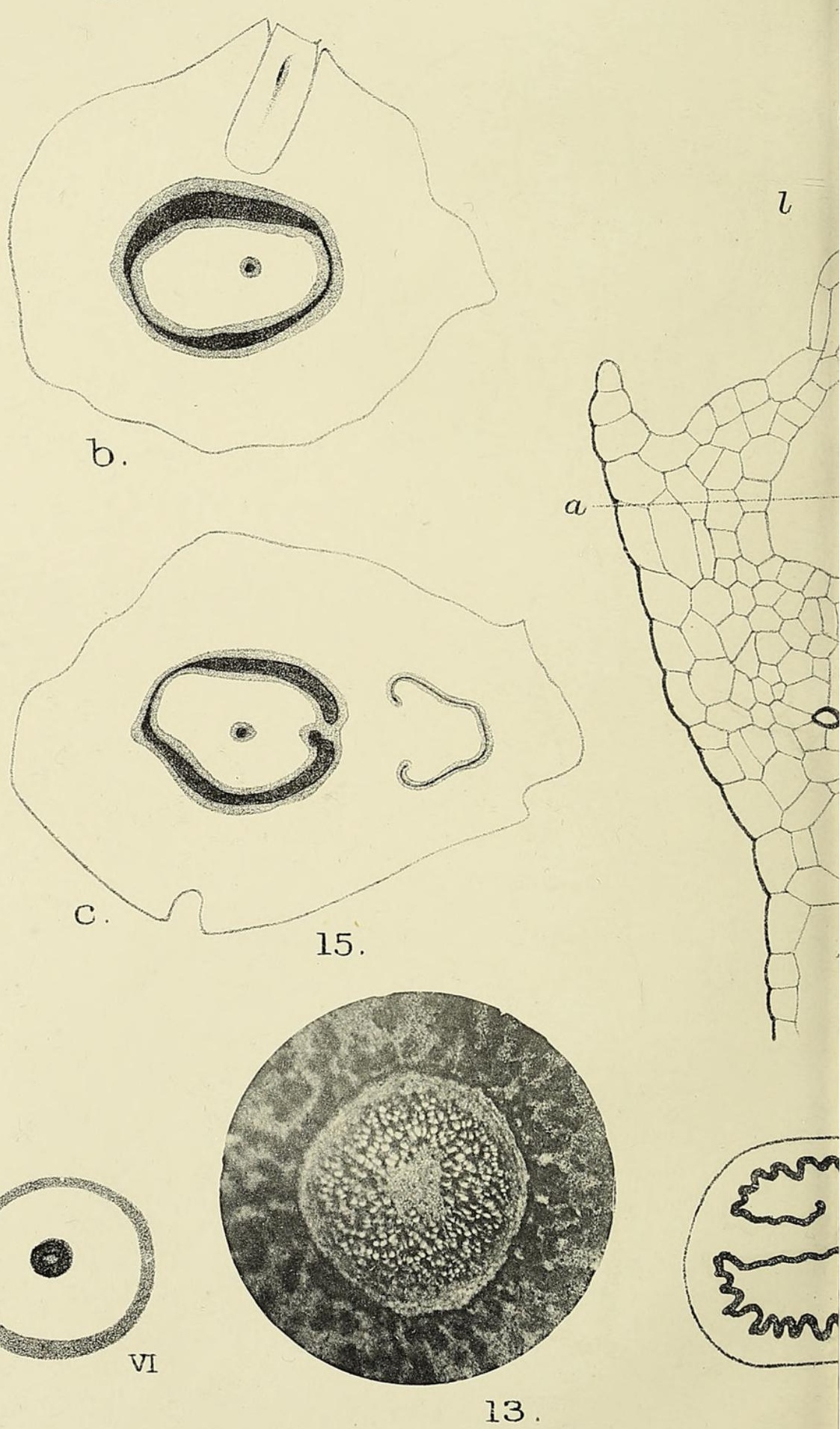

F. O.B. del

BOWER - METAXYA AND OTHER FERNS. 


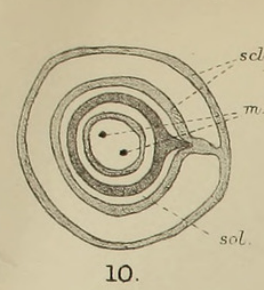

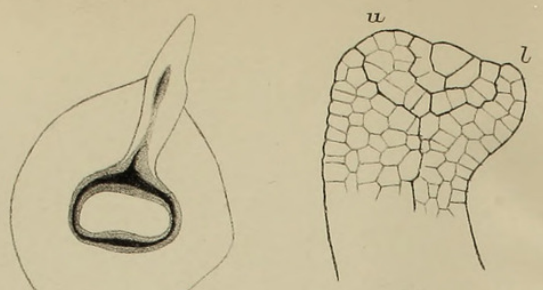

III.

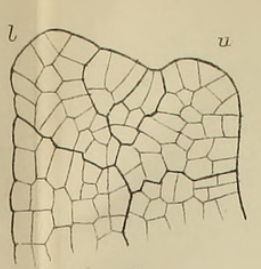

$16^{\mathrm{b}}$

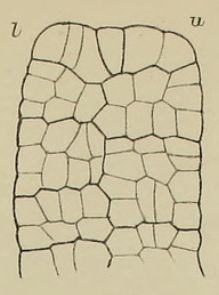

17 a
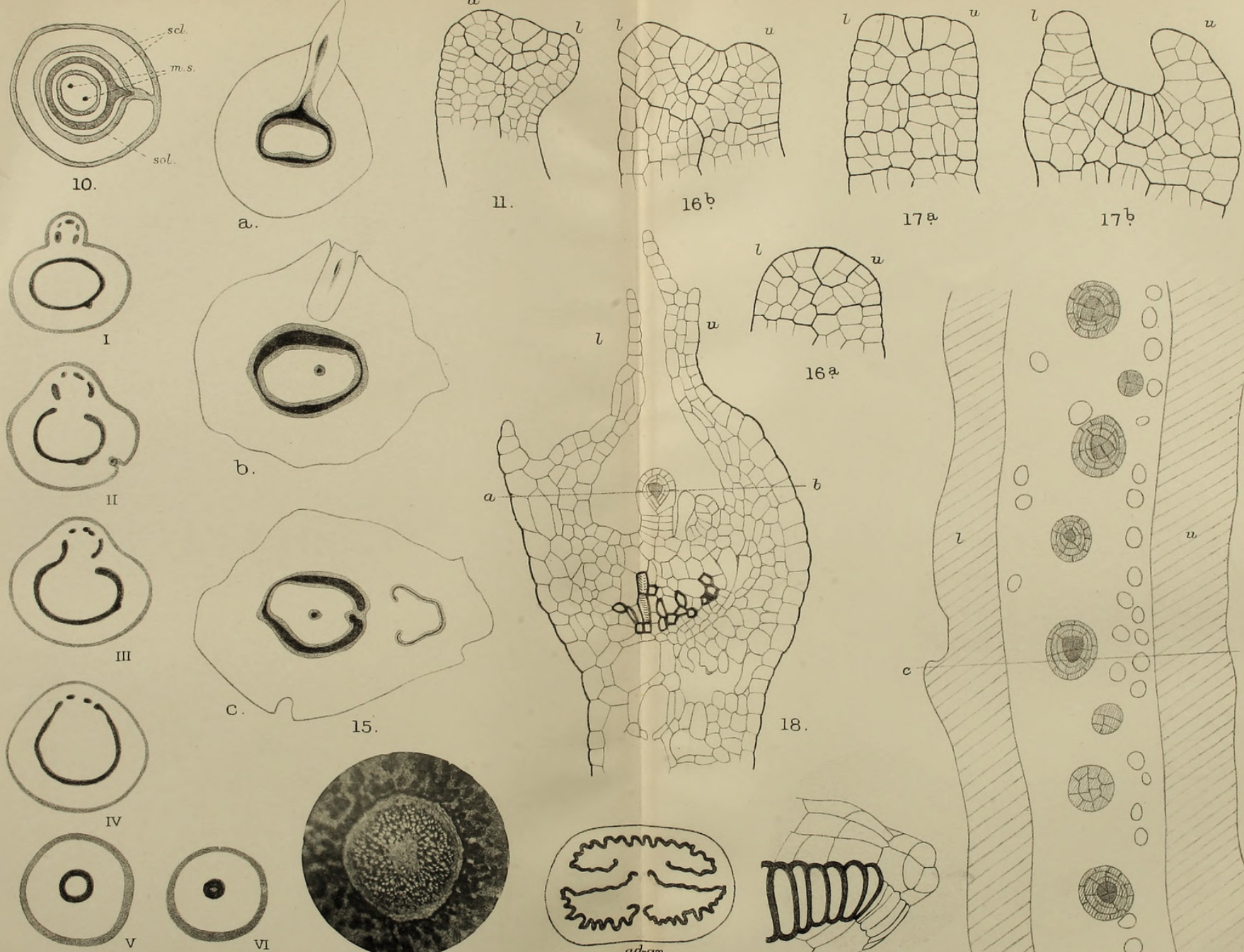

12.

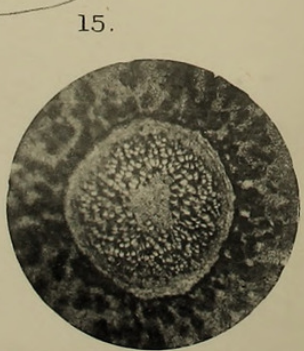

13.

17 ?

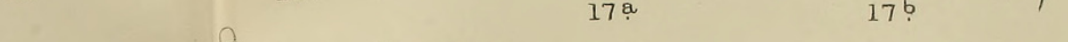

BOWER - METAXYA AND OTHER FERNS.

19 bis.

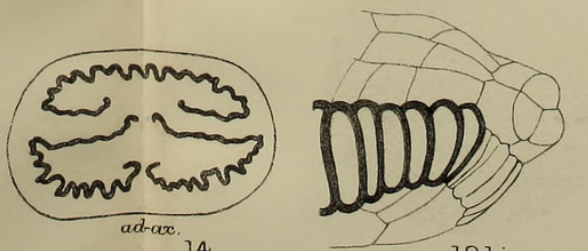

(1) 
Annals of Botany

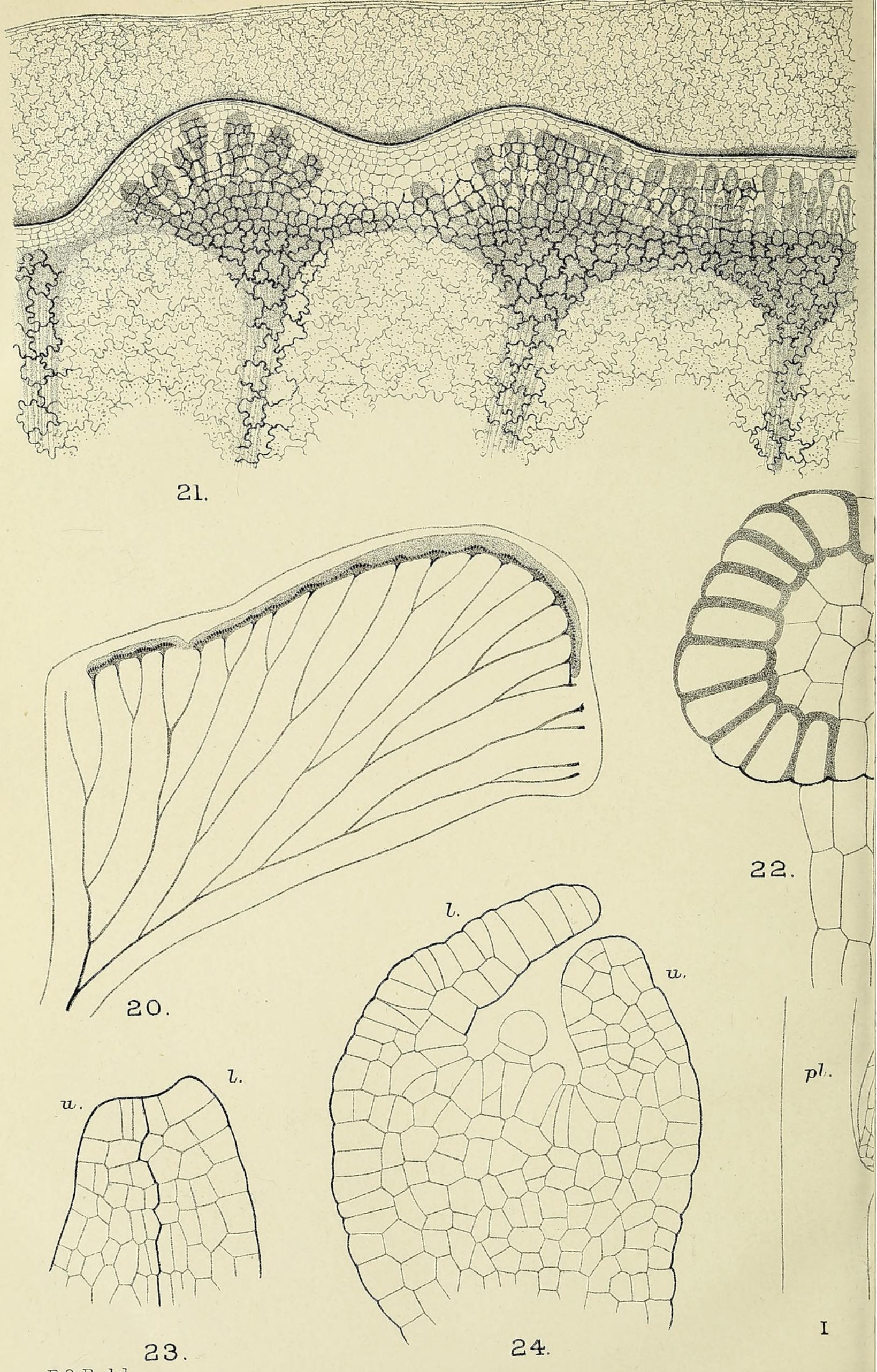

F. O.B. deI.

BOWER-METAXYA AND OTHER FERNS. 

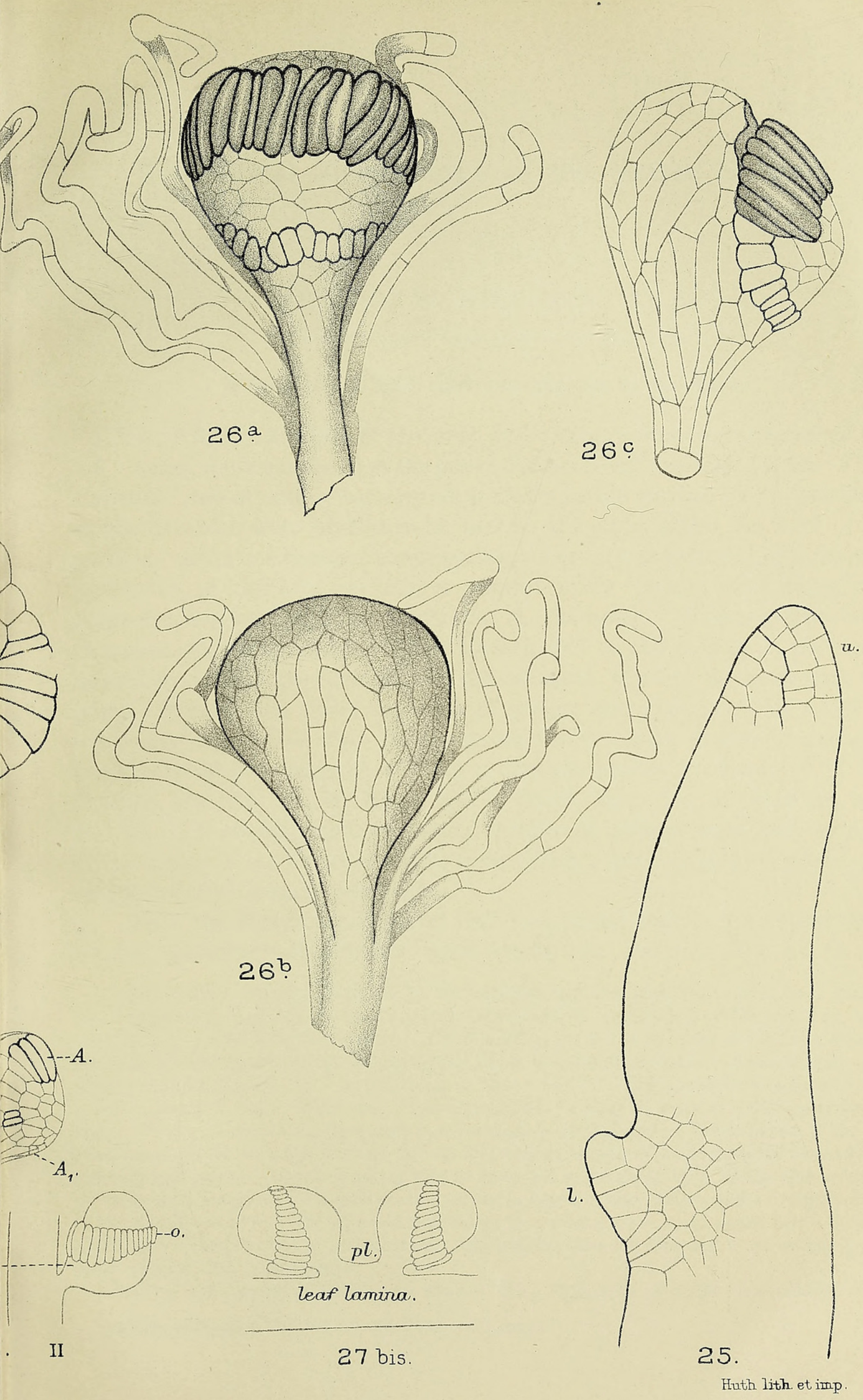

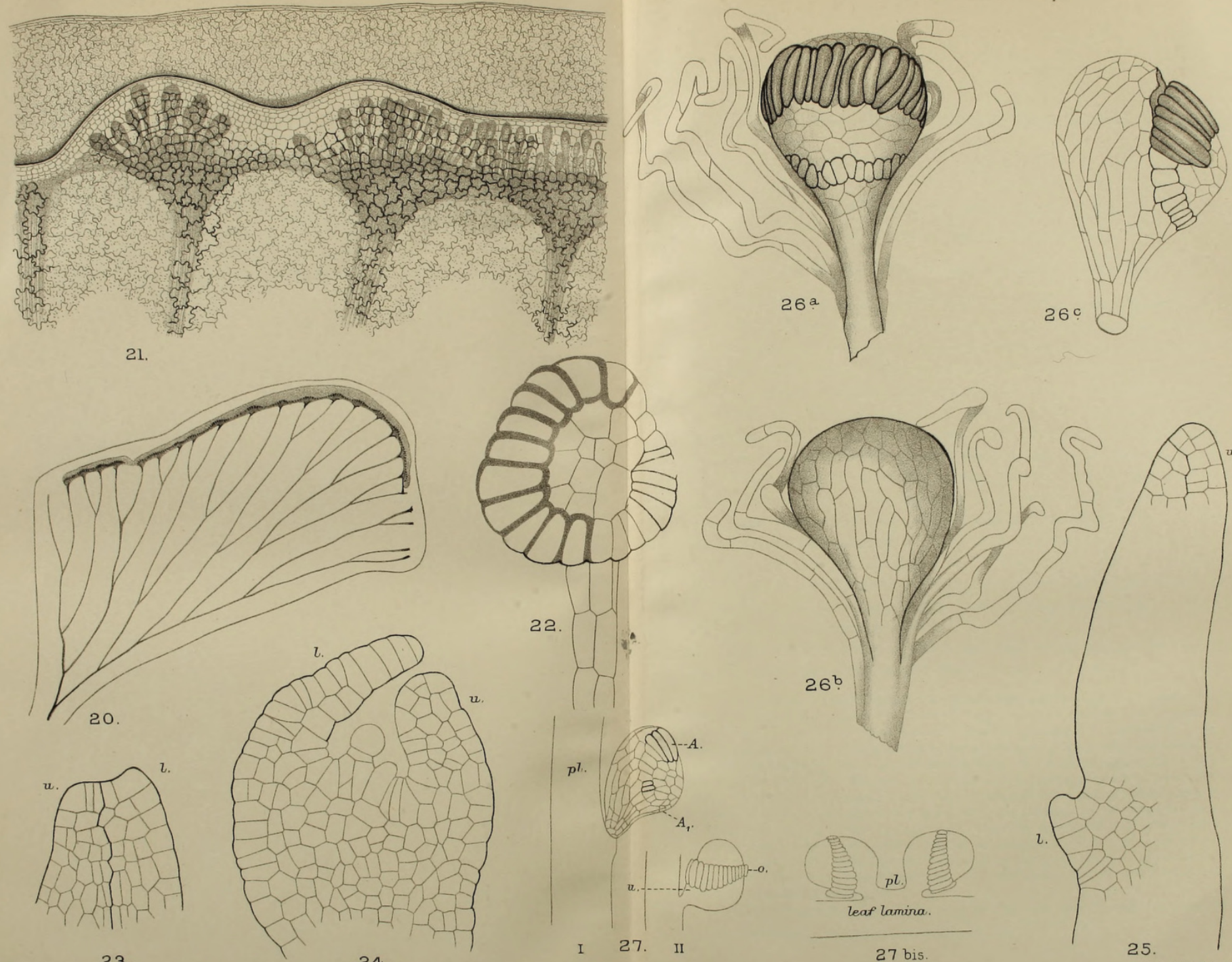

F. O.B. del.

23

24.
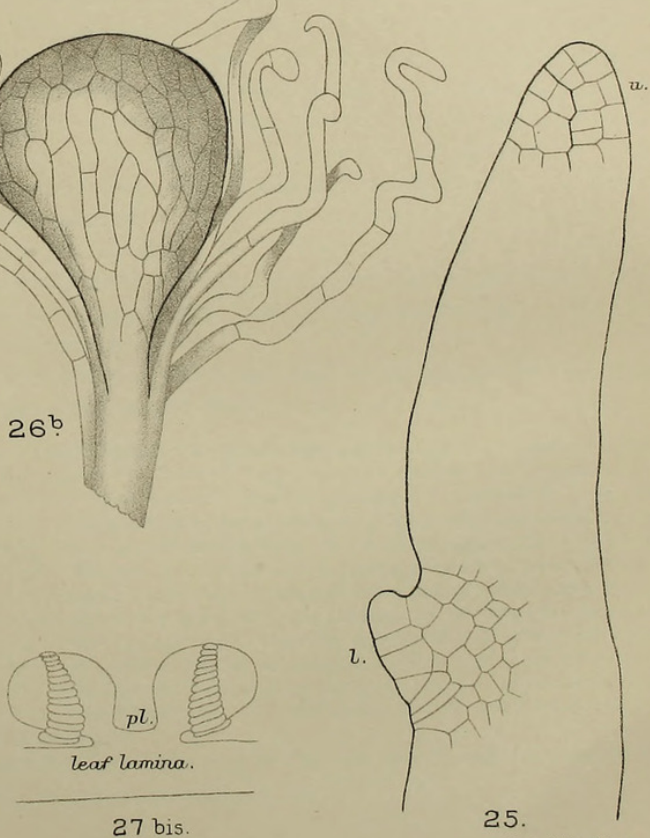

BOWER-METAXYA AND OTHER FERNS. 


\section{$2 \mathrm{BHL}$ Biodiversity Heritage Library}

Bower, F. O. 1913. "Studies in the phytogeny of the Filicales III. On Metaxya and certain other relatively primitive ferns." Annals of botany 27, 443-477. https://doi.org/10.1093/oxfordjournals.aob.a089469.

View This Item Online: https://www.biodiversitylibrary.org/item/237410

DOI: https://doi.org/10.1093/oxfordjournals.aob.a089469

Permalink: https://www.biodiversitylibrary.org/partpdf/319982

\section{Holding Institution}

Smithsonian Libraries

\section{Sponsored by}

Biodiversity Heritage Library

\section{Copyright \& Reuse}

Copyright Status: Not in copyright. The BHL knows of no copyright restrictions on this item.

This document was created from content at the Biodiversity Heritage Library, the world's largest open access digital library for biodiversity literature and archives. Visit BHL at https://www.biodiversitylibrary.org. 